\title{
ECONOMIC HISTORY REVIEW
}

\section{Building an alternative economic network? Consumer cooperation in Scotland from the 1870 s to the 1960 s}

\begin{tabular}{|r|l|}
\hline Journal: & The Economic History Review \\
\hline Manuscript ID & EcHR-15-05-0078-OA.R2 \\
\hline Manuscript Type: & Original Article \\
\hline Keywords: & Cooperatives, Alternative economic networks, Scotland \\
\hline & $\begin{array}{l}\text { There is growing interest in the ways in which, and the values according to } \\
\text { which, economic activity is undertaken. For instance, mutual ownership has } \\
\text { been identified as one means of helping to 'redeem' capitalism. This paper } \\
\text { engages with such issues by examining aspects of the behaviour of } \\
\text { consumer cooperative societies in Scotland from the 1870s to the 1960s. It } \\
\text { starts by discussing whether cooperatives represent a means of } \\
\text { conceptualising and undertaking economic activity that provides an } \\
\text { alternative to the paradigm of investor-led (neo)liberal capitalism. From } \\
\text { this, and an outline history of consumer cooperatives in Scotland, it } \\
\text { identifies two variables - dividend on purchases and funds for education - } \\
\text { as proxies for the values underpinning cooperatives' economic behaviour. } \\
\text { Analysis of these variables indicates the existence of distinct cultures of } \\
\text { cooperation, notably in the Glasgow and Edinburgh areas. The paper } \\
\text { concludes by offering two 'lessons from history' for those interested in } \\
\text { alternative economic networks. First, that cooperation can and has } \\
\text { conceptualised and sustained an alternative to the dominant (neo)liberal } \\
\text { economic paradigm. Second, that the scaling-up of such voluntaristic } \\
\text { economic thought and behaviour is unlikely to present a macro-level } \\
\text { challenge to it. }\end{array}$ \\
\hline
\end{tabular}




\section{Building an alternative economic network? Consumer cooperation in Scotland from the 1870 s to the 1960 s}

(length of text (incl. notes) 9,972 words)

\section{I}

In a recent paper for the think tank Theos, Longley observed that neoliberalism continues to dominate the political-economic landscape despite being responsible for the 'worst economic crisis for generations' ${ }^{1}$. He and others account for this by arguing that efforts to reform the economy are frustrated by 'the lack of an alternative economic theory'2. In response, Longley outlines ten principles by which economic activity should be regulated, and emphasises that their implementation requires 'both structural and personal change in the way the economy functions'3. This argument is interesting for two reasons. First, it recognises that all economic activity is undertaken in the context of economic agents' moral and ethical values ${ }^{4}$. Secondly, it emphasises the importance of the distinct but linked scales of economic activity.

This focus on scale highlights a gap in recent research into economic activity that seeks to create and sustain alternatives to neoliberal capitalism. Such studies tend to focus on the micro scale of individual enterprises, localities or networks ${ }^{5}$. This has enabled researchers to tease out the extent to which they conceptualise and practice economic alternatives to neoliberalism ${ }^{6}$. But it also reflects concern that, when scaled up, such alternatives tend to be subsumed by conventional economic values and practices, as appears to have happened to organic ${ }^{7}$ and Fair Trade T. $^{8}$ 
One of the few studies to suggest that this has not happened is The hidden alternative, an edited collection of research into cooperatives ${ }^{9}$. While the recent woes of UK cooperative enterprises question how hidden and alternative they $\operatorname{are}^{10}$, they also prompt surprise at the dearth of work on these issues ${ }^{11}$. The designation of 2012 as International Year of Co-operatives prompted several publications $^{12}$; but these also served to make visible the darkness beyond the marginalised discipline of cooperative studies ${ }^{13}$.

This paper examines the possibility that cooperatives ${ }^{14}$ represent a large-scale alternative means of conceptualising and undertaking economic activity, by analysing consumer cooperation in Scotland from the 1870s to the 1960s. In doing so, it also addresses the dearth of Scottish cooperative historiography. Discounting two recent works which consider aspects of Scottish cooperation in the context of British and European developments ${ }^{15}$, there have been only two studies in over a century ${ }^{16}$. The choice of timeframe was guided by two factors. First, aggregate data is sparse before 1872. Secondly, the 1960s saw rapid decline in the number and membership of consumer cooperatives and the cessation, in 1968 , of the payment of a dividend on purchases ${ }^{17}$.

The analysis begins by reviewing what previous studies say about the extent to which cooperation provides an alternative to joint-stock (neo)liberal capitalism (Section II). Section III outlines the development of consumer cooperative societies in Scotland from the 1870 s to the 1960s. Sections IV and V interrogate their alterity using two variables: the payment of dividends on purchases and the granting of funds for education. Section VI reflects on the 
findings and on what they tell us about current alternative economic networks.

\section{II}

Since the late 1930s, the dominant view has been that the economic development of cooperation, based on the Rochdale principles ${ }^{18}$, gradually displaced its socially transformative goals ${ }^{19}$. As Pollard put it, a growing emphasis on the creation of economic value through trading became detached from the Owenite values that inspired it, and especially the establishment of self-sustaining land-based communities ${ }^{20}$. Scholars of twenty-first century cooperation appear to corroborate this interpretation. Webster et al. argue that cooperatives are 'an alternative option within capitalism, rather than an alternative to the system itself'21; while Wilson et al. note that 'few cooperative leaders today would express an ambition to replace capitalism'22. This happened, Campbell argues, because: ' $t$ ] he movement adopted a gradualist approach to social and political change which merely facilitated the process of incorporation within the capitalist state'23. Such 'incorporation' also seems to have occurred in the 'intermediate' sector more generally ${ }^{24}$.

However, this 'incorporationist' view can be challenged by distinguishing between the rules for generating and distributing economic value, and the values that underpin and inform economic activity ${ }^{25}$. UK cooperatives differ from joint-stock capitalism because the Co-operative and Community Benefit Societies and Credit Unions Act 2010 maintains four of the eight Rochdale principles of 184426 . Moreover, there is evidence that cooperation did not abandon its non-capitalist values. Consumption became increasingly 
politicised from the later nineteenth century ${ }^{27}$ and attention - given added urgency by World War One - was paid to cooperation as an alternative to capitalism $^{28}$. Moreover, cooperative thinkers such as Jones and Holyoake ${ }^{29}$ did not abandon the aim of creating a cooperative community ${ }^{30}$. They re-imagined it on a larger scale.

'Economic and social developments made it obvious that the village community was on too small a scale and that the development of cooperative societies showed it possible to evolve, not little village communities, but cooperative organisations on a national, and perhaps even a supra-national scale; of bit by bit transforming the existing system into a cooperative one"31.

From the early twentieth century, predictions were made of a coming cooperative commonwealth ${ }^{32}$, 'the citizens of which would be in a position to regulate and determine the conditions which shall govern their lives, and thus reap the full enjoyment of the fruits of their industry'33. This would be achieved by the continued expansion of cooperation until it 'covered the whole field of human activity ${ }^{34}$. At that point, cooperation would displace capitalism as the dominant political-economic paradigm ${ }^{35}$.

Two main criticisms have been made of this scalar change in cooperative thinking. The first is that, even by 1914 , cooperation could not be considered a national movement ${ }^{36}$. Drawing on Tanner and Lawrence, Hilson argues that that the 'nationalisation' of politics was incomplete in 191437. Thus, 'the forms and meanings of cooperation differed from society to society and from place to 
place'38. The second criticism concerns the lack of a coherent theory of the cooperative commonwealth ${ }^{39}$ and of detailed plans for bringing it into being ${ }^{40}$.

While not challenging the accuracy of these criticisms, efforts have been made to blunt them. Gurney argued that the practical but inarticulate knowledge held and acted on by co-operators has been overlooked by academic historians with a predilection for 'texts and an explicit and fully-articulate body of knowledge'41. Bonner ascribed co-operators' failure to develop a coherent body of theory to the combination of the collapse of the Owenite communities and to Marx's 'scientific socialism', both of which highlighted the risks of trying to predict the direction of social evolution ${ }^{42}$.

Despite its lack of doctrinal clarity, from the 1890s to the 1930 s cooperation was seen as a threat to liberal capitalism ${ }^{43}$. For example, manufacturers often tried to prevent cooperatives paying dividend on branded goods through resale price maintenance 44 . There were also several instances of traders coming together to boycott cooperatives in an attempt to starve them of merchandise, the largest of these occurring in the Glasgow area in the $1890 \mathrm{~s}^{45}$. It is hard to square such hostility with the 'incorporationist' view.

However, just because cooperative thinkers were predicting the evolution of a cooperative commonwealth, it does not necessarily follow that this reflected thinking in individual societies. For although the movement possessed influential national bodies, such as the Co-operative Union (CU), the Cooperative Wholesale Society (CWS) and the Scottish CWS (SCWS), retail societies were local and guarded their independence ${ }^{46}$. Thus, as late as the 
inter-war period 'the cooperative movement operated as a national movement but functioned as one comprising individual, autonomous societies'47. For some contemporaries, this was vital for the health of cooperative democracy 48 .

Although most cooperative historiography has focused on the local and national scales, relationships and developments at intermediate spatial scales also appear to have been significant. For example, a few studies of UK cooperation focus on distinct regional economies, such as South Wales and greater Glasgow ${ }^{49}$. Others have also hinted at the existence of 'regional'50 cooperative cultures. For instance, Carr-Saunders et al. argued that societies in Scotland and northern England tended to pay higher dividends than those in the midlands and south of England51. They also posited the operation of a 'neighbourhood' effect, whereby 'dividends in any one district are usually at about the same level'52. These distinct (but related) scales of cooperation complicate attempts to examine whether, and to what extent, the movement presented a practical and conceptual alternative to liberal capitalism. Hence, studies have begun to explore the spatial and scalar dynamics of the movement ${ }^{53}$.

As the main aim of this paper is to analyse the extent to which cooperation conceptualised and practiced an alternative to liberal capitalism, with a view to informing debate over the extent to which current alternative economic networks can do so, the following sections examine important aspects of cooperative thinking - manifested primarily at the national level - and local retail societies' behaviour from the 1870 s to the 1960 s. Sections IV and V justify the use of, and analyse Scottish consumer cooperative societies' 
behaviour concerning, the two variables chosen for this analysis - the payment of dividend on purchases and the granting of funds for education - at roughly decennial intervals between 1872 and 1961 .

Doing so will also address this paper's second aim: to contribute to Scottish cooperative historiography. The analysis will be sensitive to the spatial and scalar differences outlined above; though detailed local comparisons must await future research. Given the paucity of previous work, and in order to contextualise the analysis in sections IV and V, section III outlines the trajectory of Scottish consumer cooperation between the 1870s and the 1960s.

\section{III}

Although there were commonalities between the development of consumer cooperation in Scotland and elsewhere ${ }^{54}$, there were also differences.

Registration and reporting were devolved, Scotland having its own Registrar 1846-75 and Assistant Registrar thereafter55. There were organisational differences within the cooperative movement, notably the existence of the SCWS 1868-1973. The importance of the SCWS and of England's CWS, on which it was modelled, to the development of consumer cooperation is hard to over-state, and their practices differed in several respects 56 . For instance, it can be argued that, in terms of expanding the scope of cooperation, the SCWS - through its payment of a 'bonus on wages' $1892-1922^{57}$ and its opening of retail branches from the $1900 s^{58}$ - was sometimes more progressive than the CWS. Further evidence for the distinctiveness of Scottish cooperative culture is the publication of The Scottish Co-operator from 1893, which aimed to spread knowledge of Scottish cooperation, and the social reform that it aimed 
to bring about, beyond those who attended meetings ${ }^{59}$. William Maxwell President of the SCWS 1881-1908 - observed that Britain's first recorded consumers' cooperative was in Ayrshire and that 'Owen's first social improvements were begun in New Lanark'60. Although Maxwell61 forestalls accusations of chauvinism (which, given his presidency of the International Co-operative Association, would in any case be hard to substantiate), his observations seem calculated to make the case that, while Scottish cooperators embraced English innovations, the country had a documented tradition of cooperation of which it could be proud.

One disadvantage of that distinctiveness is a paucity of public records. Until W. Guthrie's appointment as Registrar in 1871, data collection (despite cooperative societies being required to submit an annual return) and the keeping of the official register appear to have been lax ${ }^{62}$. This can be demonstrated by comparing the Scottish Registrar's annual returns to Parliament for 1871 and 1872. The former, data for which would have been gathered in 1872, when Mr Guthrie was starting to put matters in order, contains data from seventy societies, just over a quarter of those registered ${ }^{63}$. The following year, the return rate was almost three-quarters (173 societies) ${ }^{64}$. Thus, 1872 is probably the first year for which credible, Scotland-wide data on cooperative societies exists. Although few other returns from Scotland's Registrars appear to have survived, the CU collated and published returns from cooperative societies in its annual Co-operative Congress reports from the mid 1870s, most of which are extant65. These, in conjunction with the Registrar's return for 1872, make it possible to examine aspects of the behaviour of cooperative societies throughout Scotland from then on. 
Consumer cooperative societies proliferated in Scotland after 1860. The surviving register (probably started during Mr Guthrie's tenure) lists four societies as being registered before 1860 . This seems too low, as directories of cooperative societies, published by the CU from 1872, list at least sixty-three which claimed to have been founded before 186066. Between 1860 and 1870, the register records a net growth of 198 societies (Table 1). Rising real incomes played a part in this ${ }^{67}$, along with the diffusion of the Rochdale principles ${ }^{68}$. However, the greatest single influence was probably the passing of the 1862 Industrial and Provident Societies Act ${ }^{69}$. Drafted primarily by Edwin Vansittart Neale $^{70}$, this Act exempted cooperatives from taxation of their profits ${ }^{71}$ and made it legal for them to allocate funds for educational purposes, something the English Registrar had considered illegal since $1855^{72}$.

\section{TABLE 1 ABOUT HERE}

As Table 1 shows, net registrations declined sharply after 1870, becoming negative after 1900. These figures are similar to those derived from the CU's directories and Congress reports; though the latter show the number of Scottish cooperative societies declining from about 1891. No later register survives, but CU Congress reports chart a decline in society numbers from 312 in 1891 to 168 in 1961.

FIGURE 1 ABOUT HERE 
By the early 1870s therefore, Scotland's cooperative movement was well established. Subsequently, although the number of societies grew slowly before declining, membership grew quickly. From 42,628 in 1872, it reached 315,432 in $1901,771,707$ in 1931 , and peaked at 1,442,369 in $1961^{73}$. Figure 1 charts cooperative society membership as a percentage of the Scottish population. It shows consistent growth from the 1880s until, at its peak in the 1960 s, over a quarter of the population belonged to a cooperative.

However, Figure 2 shows that cooperative society membership was unevenly distributed across Scotland's thirty-two historic counties ${ }^{74}$. To take account of the counties' different populations, membership is mapped using location quotients $(\mathrm{LQ})^{75}$. An LQ of 1.0 indicates that a given county contained the number of cooperative society members that would be expected if membership were distributed evenly throughout Scotland. An LQ of less than 1.0 indicates that there were fewer members than would be expected according to this hypothesis; an LQ of more than 1.0 indicates that there were more. Figure 2 adopts a more conservative estimate of the significance of an LQ than the median found by Crawley et al. ${ }^{76}$. Thus, an LQ of more than 1.5 is taken to indicate a county with an unusually high concentration of cooperative society members.

FIGURES 2a-d ABOUT HERE

Figure 2a shows seven counties with unusually high concentrations of cooperative society membership in 1872: Clackmannanshire (LQ=11.25); Selkirkshire (9.2); Stirlingshire (2.97); Fife (2.62); West Lothian (2.2); East 
Lothian (1.80); and Ayrshire (1.58). Higher concentrations are evident in central and eastern counties, with negligible or no membership in more remote and rural areas. The low concentration of cooperative members in Lanarkshire $(\mathrm{LQ}=.66)$ merits comment, given that it contained Glasgow. This probably reflects economic conditions in the burgeoning 'second city of Empire'. Glasgow's working classes were beset by a combination of low pay, large-scale cyclical unemployment and high housing costs ${ }^{77}$, and membership of cooperative societies increased slowly until about $1890^{78}$. The cooperative movement in the nineteenth century has been criticised for its failure to reach large sections of the poor ${ }^{79}$ and, while local studies elsewhere have begun to challenge this view ${ }^{80}$, the limitations of surviving data make an assessment of such claims difficult in Glasgow ${ }^{81}$. Nevertheless, Campbell argues that Glasgow's cooperative society members probably commanded above-average purchasing power and tended not to regard themselves as poor ${ }^{82}$. Indeed, Glasgow co-operators became increasingly aware that poverty excluded many of their fellow citizens from cooperation. In 1903, a conference of Glasgow societies advocated the opening of branch stores in poor areas, and the city's St George Society got at least as far as identifying a possible location for the first of these ${ }^{83}$. However, any such experiment, if it was carried out at all, is likely to have been short-lived. The St George society undertook retrenchment in 1907 after the onset of a severe economic downturn ${ }^{84}$. It seems likely, therefore, that in Scotland in the last quarter of the nineteenth century there was an inverse relationship between cooperative society membership and poverty. 
Figures $2 \mathrm{~b}-2 \mathrm{~d}$ show a gradual reduction of county-level differences in cooperative society membership. This can be seen in the declining number of counties with LQ above 1.5 (seven in 1872, three in 1961) and also in the declining values of those LQ. For instance, the LQ for Clackmannanshire, the highest throughout this period, fell to 3.89 in 1901 and 1.88 in 1961 .

Nevertheless, the geography of high LQ demonstrates continuity.

Clackmannanshire, Stirlingshire and Selkirkshire retained high concentrations of cooperative society membership between 1872 and 1961; although the latter's LQ had fallen to 1.41 by 1961 . Thus, Figure 2 argues for the existence of regional cooperative cultures in Scotland between the 1870s and the 1960s. This argument rests on the basis that a key component of culture is tradition: 'an intentionally selective version of a shaping past and a pre-shaped present, which is then powerfully operative in the process of social and cultural definition and identification'85. It is clear that certain parts of Scotland maintained a tradition, between the 1870s and the 1960s, of relatively high levels of cooperative society membership. Why they did so is as yet unclear, but it seems that regional cultures of cooperation developed and persisted.

\section{IV}

The payment of a dividend on purchases was, in Holyoake's view, a decisive contribution to consumer cooperation made by the Rochdale principles ${ }^{86}$. One consequence of its operation was that cooperative societies did not seek to sell to their members at the lowest price possible (i.e. one that would just cover operating costs). An exception that proves this rule is the professional supply associations, several of which registered as cooperative societies in the 
nineteenth century. For instance, Edinburgh's Professional and Civil Service Supply Association, which was registered as a cooperative from at least the early 1870s until converting to a company in 1912, made a profit on sales in the range 0.51 to 1.51 per cent and never declared a dividend. While this made them non-capitalist, it also made them non-cooperative: "profit is not saved for the consumer, no educational advantages are furnished, no social life cultivated, [and] no social principle is asserted's7.

Thus, for cooperative thinkers such as Holyoake, societies could best serve their members by trading profitably and by devoting the accumulated capital to the improvement of their lot. Indeed, the more capital that cooperative societies could accumulate, the better for their members. With it, they could expand the range of goods they sold and widen their membership by opening new branches. They could invest in land and house-building, thereby providing homes for members. By devoting a proportion of profits to education, they could contribute to members' intellectual development. And by trading with, and investing in, other cooperatives, they could strengthen the movement ${ }^{88}$.

Therefore, it should be "the policy of the [cooperative] store to sell at the highest market price, since the higher the sale price the higher the dividend, and the more the member saves's9. Dividend, therefore, had a moral purpose: it helped to redistribute wealth more equitably 90 and it taught the value of economy ${ }^{91}$. Thus, the generation of a healthy profit not only helped to raise cooperators economically, by paying them a dividend, it also helped to raise them morally, by teaching them the value of thrift. As Holyoake put it, 
'cooperators were never the enemy of capital'92. Instead, their aim was to ensure that it was distributed fairly. Thus, far from indicating a move away from cooperative principles, the payment of dividend on purchases was both a moral good and an important component of cooperative ideology 93 .

Thus, even in their aim to run profitable enterprises, cooperative societies could be said to be alternative economic networks. This is because they were, to paraphrase Whatmore et al. ${ }^{94}$, redistributing profits (via dividend on purchases) against the logic of conventional capitalist practice. The extent to which Scottish cooperative societies did so can be seen in Figure 3, which plots net profit against dividend as a percentage of purchases, at decennial intervals between $1881^{95}$ and 1961. The impact of macro-economic developments appears obvious: with profitability dipping significantly in the recessions that followed the post-war economic booms. Though it is striking how well they held up after the onset of the Great Depression, evidence from Wales provides a possible explanation: the Ton and Ewloe Place societies suffering much less than might have been expected during times of economic hardship due to high levels of member loyalty ${ }^{96}$. The decline in profitability after 1951 has been ascribed to three main factors: the growing dominance of multiple retailers and branded-goods manufacturers; the political neglect of organised consumerism in favour of the culturally-constructed 'sovereignty' of the atomised consumer; and the cooperative movement's ambivalence towards hedonistic consumption and its consequent lack of engagement with fashion retailing 97 .

FIGURE 3 ABOUT HERE 
Figure 3 suggests that average rates of dividend tended to be closely related to profit. The strength of this relationship was tested using Pearson's correlation coefficient $(r)^{98}$. This yielded $r=0.98$, a very strong positive correlation between net profit and level of dividend per pound spent. Nevertheless, while the relationship was close, it did change. For example, between 1911 and 1941 there was a tendency to pay lower dividends relative to net profit ${ }^{99}$. A partial explanation for this is the introduction, during World War One, of Excess Profits Duty, which aimed to curb profiteering by subjecting all profits in excess of pre-war levels to punitive taxation ${ }^{100}$. This duty made cooperative societies' profits subject to tax for the first time since 1862; a situation that persisted throughout the inter-war years ${ }^{101}$.

Figure 3 shows that, on the whole, Scottish societies set dividends at a level that could be justified on the basis of profits. However, as cooperative membership grew, so did a perception that increasing numbers joined solely for the dividend. In other words, concern grew that an increasing proportion of members wanted the value distributed through the dividend but were indifferent to the values of cooperation. Holyoake's condemnation was forthright: 'he who cares only for the highest dividend...is a mere competitor, and the cooperative principle is not in him'102. Maxwell called such members 'drones'103. This issue was raised repeatedly in The Scottish Co-operator'104: a 1925 editorial complaining that the "dividend mind" is far too active amongst our members, and too often mars by its littleness the effect of our nobler principles'105. 
Such concerns suggest that, as the movement grew, societies came under increasing pressure to pay large dividends. The annual Congress reports published by the $\mathrm{CU}$ provide data with which to test this hypothesis. However, there are confounding factors. There was, for instance, no consensus about what constituted an appropriate level of dividend ${ }^{106}$. The circumstances of individual societies could vary greatly due to local factors: from microeconomic changes to the conduct of elected officials and employees. There was also the 'neighbourhood' effect noted above. By the early twentieth century, many urban areas contained several cooperative societies and their dividend levels were often similar ${ }^{107}$. Thus, it seems probable that societies set dividend levels with an eye to those of their neighbours; not least because of the danger of capital flight to nearby societies should they reduce their dividend unilaterally ${ }^{108}$.

Nevertheless, on the basis of the argument made above, it is reasonable to look for evidence of distinct regional cooperative cultures based on the levels of dividend that societies paid out over time. The case for postulating the existence of distinct cooperative cultures on the basis of dividend payments ${ }^{109}$ is strengthened by the geography of Scottish consumer cooperative societies that paid a dividend to their employees (termed 'bonus on wages' by the CU). Of the nine CU Congress reports examined, only those for 1901, 1911 and 1921 record such payments. No Scottish society paid a 'bonus on wages' in each of these years, but of those that did so at least once, almost two-thirds were located in Lanarkshire, Glasgow or Renfrewshire. Thus, it was primarily societies in Scotland's industrial heartland that sought to extend cooperative 
values to the workplace, through the mechanism of 'bonus on wages', between the late 1890 s and the early 1920 s.

Other things being equal it could therefore be argued that a commitment, on the part of societies located in the Glasgow area to spread the benefits of cooperation beyond their consumer membership, might have been accompanied by the payment of lower dividends on purchases than the national average, as both would have an impact on net profits. Conversely, it could be argued that areas where larger than average dividends were paid might have a culture of cooperation more in tune with the so-called 'dividend mind'.

To test these propositions, Society returns published in CU Congress reports were examined - at decennial intervals between 1881 and 1961 - for societies that paid high or low dividends. Across the period, between 24.4 and 29.7 per cent of societies paid an average dividend that was at least one standard deviation above or below the national mean. Of these, societies based in Midlothian (including Edinburgh) seemed more likely to pay high dividends, with those in Lanarkshire (including Glasgow) being more likely to pay low dividends. Given that the dividend paid by a society is unlikely to have been independent of that paid by its neighbours, a non-parametric test was used to evaluate the significance of this geographical distribution. The large samplesize $(n>20)$ version of the Mann-Whitney $U$ test was applied, in which a value for $z$ is derived from $U^{110}$, on data for $1881,1901,1931$ and 1961 . The results were: $1881, U=73, z=-3.86, \mathrm{p}<.001 ; 1901, U=86, z=-5.46, \mathrm{p}<.001 ; 1931$, $U=9.5, z=-4.33, \mathrm{p}<.001 ;$ and 1961, $U=141.5, z=.005, \mathrm{p}=.48)$. In 1881,1901 
and 1931 the null hypothesis (that both data sets are drawn from the same population ) can be rejected because the inverse geography observed in the data - societies in Midlothian tending to pay higher dividends than societies in Lanarkshire - is statistically significant at the $99.9 \%$ level $(\mathrm{p}<.001)$.

The fact that consumer cooperative societies in Glasgow and Lanarkshire were paying relatively low dividends on purchases in 1881, 1901 and 1931, combined with the fact that societies in Glasgow, Lanarkshire and Renfrewshire made up almost two-thirds of those paying a 'bonus on wages' between 1891 and 1921, and the fact that the Glasgow-based SCWS also paid a 'bonus on wages' between 1892 and $1922^{111}$, indicate that cooperative culture in the Glasgow area was distinct. Indeed, although the early growth of cooperation in the region was probably linked to the dominance of radical liberalism, with its emphases on individual and mutual self-help ${ }^{112}$, there is evidence that, from the 1890 s, co-operators started to align themselves with labour politics. For example, the Scottish Co-operative Women's Guild - the first section of which opened in Glasgow in 1890 - sent its first petition for female suffrage to the government in $1893^{113}$. Co-operators were also foundermembers of Glasgow's Workers' Election Committee in $1896^{114}$ and the Scottish Workers' Representation Committee in 1899115. In addition, Campbell charts the close working relationship that developed between cooperative societies and trade unions ${ }^{116}$. For example, several large Glasgow societies dealt only with those non-cooperative suppliers which paid trade union rates, and provided considerable financial assistance to workers involved in industrial disputes ${ }^{117}$. From the late 1880 s, moreover, Glasgow area cooperators bore the brunt of the UK's most significant and sustained traders' 
boycott ${ }^{118}$, which Smyth suggests spurred them to sustained political involvement ${ }^{119}$. Thus, current evidence points to the development and maintenance of a distinct cooperative culture in the Glasgow area.

By contrast, societies in Edinburgh and Midlothian appear to have had a tradition of paying relatively high dividends on purchases. This suggests that cooperative culture in this area was influenced by the 'dividend mind'. So too does the fact that Edinburgh's St Cuthbert's Co-operative Association (SCCA) was taken to task by The Scottish Co-operator in the early 1930s for consistently paying high dividends in the face of worsening economic conditions $^{120}$. Board minutes from the inter-war years show that the SCCA sought repeatedly to find ways of reducing retail prices in order to help members in 'reduced circumstances'121. However, in 1931 these efforts foundered on the realisation that they would entail reducing working expenses or dividend ${ }^{122}$. This reflects a reluctance to reduce dividend on the part of SCCA Board members. For instance, in March 1930 the Drapery, Boots, Drugs, Coal \& Laundry Committee voted thirteen to seven in favour of increasing dividend by a penny, to three shillings and seven pence in the pound ${ }^{123}$. This, in turn, probably reflects the structure of the area's economy. In the early twentieth century Edinburgh remained a significant financial centre, although its size was rivalled by Glasgow's ${ }^{124}$. However, it had not had anything like Glasgow's growth in manufacturing employment and population ${ }^{125}$. Thus, Edinburgh's occupational structure was different. For much of the nineteenth century, for example, about one in eight men was involved in a profession, compared to one in twenty in Glasgow ${ }^{126}$. Moreover, Edinburgh's working classes were segmented in 'a wide variety of smaller-scale 
and labour-intensive industry'127. Indeed, in the 1920s the SCCA was the city's largest single employer ${ }^{128}$. These factors, taken with the apparent cultural dominance of the middle classes ${ }^{129}$ and the likelihood that the area escaped the worst of the Depression, suggest that the Edinburgh region's cooperative culture differed markedly from that of Glasgow's.

\section{$\mathbf{V}$}

Although there was no consensus about the most appropriate level of dividend to be paid on members' purchases, there was agreement at the UK level about the appropriate level of funding for educational activities. Rochdale's Equitable Pioneers Society was the exemplar, devoting 2.5 per cent of net profits to education from 1844; and the Co-operative Congress of 1870 resolved to urge all societies to do likewise ${ }^{130}$. Education had long been seen as the key to social transformation'131 by cooperators. Thus, educational provision was a source of continuity, as the movement had, 'since the days of Owen, stressed the morally educative influences of collaboration as against the selfish motives of competition,...sought to implement educational and ethical aims, and... aimed to make not only a wealthier but a better people'132. Thus, educational provision by the cooperative movement has long attracted critical attention.

Cole argued that educational provision deteriorated as the movement developed economically. For Owenites, a mastering of certain attitudes and ideas was vital for 'healthy conditions of social living'133. To achieve this, children must be raised to understand cooperation as the basis for social well- 
being, while adults needed to unlearn old, immoral ways in order to be able to do so. By the 1870s, however, the Rochdale society was not trying to educate its members in any formal way about cooperation or citizenship or any of the subjects to which Owenites would have given pride of place. It was dispensing knowledge pretty much as it sold tea or bread guaranteeing that its quality was unadulterated and trying to give its members what they appeared to want in the spirit of a 'general provider', but no longer regarding itself as having a mission to use education as a direct instrument for bringing nearer the cooperative commonwealth ${ }^{134}$.

This view corroborates a report of 1889 on the administration of educational funds by societies ${ }^{135}$. Rochdale's provisions were prodigious - including eighteen reading rooms and a library containing almost 17,000 volumes - but their classes, in which around 4.5 per cent of members were enrolled, covered a range of subjects that appeared to have little to do with cooperation.

However, as state education improved after 1870, through the introduction of compulsory schooling for children and the opening of public libraries, the rationale and provision of cooperative education changed ${ }^{136}$. These changes are best understood in the context of the types of education that cooperators thought important. As Rochdale's example shows, education in established branches of knowledge was valued highly. Instrumental education, from the teaching of basic literacy and numeracy to the application of scientific knowledge to manufacturing, could help individuals to 'get on' in life by obtaining more skilled, better-paid and preferably independent employment. 
Many late-nineteenth century cooperators 'found it difficult to disentangle material deprivation from intellectual deprivation and argued therefore that the movement should supply the educational as well as the bodily needs of its members'137. This was linked to a belief that education should help members to become critical thinkers on a level with those in positions of social and epistemological authority ${ }^{138}$. Thus, although cooperative provision of some instrumental education became unnecessary after $1870^{139}$, the movement continued to support access to specialist and critical education for members, for instance by promoting university extension courses ${ }^{140}$ and, from 1891 , providing scholarships for university summer schools ${ }^{141}$.

Moreover, state provision of education was thought to render cooperative provision more necessary. As a letter to The Scottish Co-operator argued: 'much of the public education is very individualistic in its tendency, and unless counteracted by cooperative influences must tend to increase many of the evils of the competitive system'142. This was not an isolated view. 'Many cooperators argued that state education performed an important ideological function, helped to structure and reinforce capitalist relations of production and reproduction and rendered the working class dependent and divided'143. For Holyoake, education in cooperative values was vital for cooperators, as was their application to the business of cooperation ${ }^{144}$. He put it bluntly. 'Without knowledge, self-help can do nothing'145. Thus, the movement came to the view that the values of cooperation had to be taught alongside the practical skills necessary for it to produce economic value ${ }^{146}$. In this way, 'cooperation creates a new person, a new character, and a new policy'147. 
The fruits of this can be seen in Twigg's 1924 survey of cooperative education, which divides the examinations offered by the CU into six categories: cooperation, with streams for juniors and adults, the latter offering a range of qualifications up to Honours level; history; economics; citizenship; technical, including book-keeping, management, and courses on law and accounting for society secretaries; and 'miscellaneous', mostly teaching, qualifications ${ }^{148}$. From twenty-five (adult) students qualifying in 'elementary' cooperation in 1887, 7,299 passed CU examinations in 1913, predominantly in cooperation, management and book-keeping ${ }^{149}$. Thus, not only did cooperative educational provision expand after 1870 , it was also brought back in line with the Owenite emphasis on training people to become cooperators.

Nevertheless, the number of people taking CU courses and passing examinations was tiny compared to the membership of cooperative societies. For example, the number passing CU examinations in 1913-14 represented less than a quarter of one per cent of total membership ${ }^{150}$. In addition, and despite their best efforts, lectures organised by local societies were often poorly attended ${ }^{151}$. While these facts are consistent with the claim that ordinary members were indifferent to cooperative values ${ }^{152}$, there was more to cooperative education than formal classes and qualifications. Because the practice of cooperation was considered a moral good, 'membership in a cooperative society is a useful education in itself ${ }^{\prime 153}$. Thus, Maxwell argued, some of the 'drones' who joined societies solely in order to earn dividend would, in time, begin to take an interest in cooperative values and their application ${ }^{154}$. Similarly, Holyoake observed that, although people might initially be tempted to spend any increase in their earnings (e.g. through 
receipt of dividend) on 'enjoyment', 'after a time the unaccustomed pleasure satiates and palls, and they sober down and live a self-respecting life'155. Thus, by engaging in cooperation and being exposed to cooperative values and culture, even the most dividend-minded members could develop into cooperators.

By this logic, it was not necessary for educational spending to focus solely on formal education. As Joseph Reeves, Education Secretary of the Royal Arsenal Co-operative Society ${ }^{156}$, argued, the organisation of cultural activities - such as choral, orchestral and dramatic societies, along with Sunday societies (for showing plays and educational films) and even physical activity such as Margaret Morris Dancing - were legitimate educational activities provided that they 'aim at a general improvement in the cultural life of our members so that they possess a capacity to understand and appreciate the great arts'157. Thus, although societies were criticised for allotting educational funds to what some considered 'frivolous' social activities ${ }^{158}$, these could play a role in fostering cooperative culture by encouraging social intercourse among members ${ }^{159}$.

It would be hard to quantify the contribution of formal and informal education, let alone the day-to-day practice of cooperation, to the achievement of the movement's values and aims. Nevertheless, the foregoing discussion indicates that a society's spending on educational activities can serve as a proxy for its commitment to cooperative values beyond the generation of sufficient profit to pay a dividend. As grants for educational purposes were reported in CU returns, they were analysed for insights about Scottish societies' commitment to cooperative values. 
Overall, Scottish societies fell short of the CU's recommendation to spend 2.5 per cent of net profits on education. Across the nine sets of returns examined (1881-1961, at decennial intervals), only twelve societies reached this target, none doing so more than once. Moreover, although the proportion of Scottish societies devoting funds to education more than doubled between 1881 (20.27\%) and 1911 (53.05\%), it stabilised thereafter, averaging 53.76 per cent 1911-61.

Lucas chided Scottish societies for spending less on education than their English counterparts ${ }^{160}$. CU Congress reports confirm that, between 1901 and 1951, the mean educational grant of Scottish societies was between two-thirds and three-quarters of the UK mean. However, Scottish societies were small (in terms of membership) by UK standards. A comparison in the $1951 \mathrm{CU}$ Congress report shows that, while the percentage of profits devoted to education by Scottish societies was third lowest of its nine UK regions, their mean education spend per member was second highest. This is contextualised in Figure 4, which shows that, from a low base in 1891, Scottish societies' spending on members' education grew rapidly and, from 1921, was larger (per member) than that of UK societies as a whole.

FIGURE 4 ABOUT HERE

Given the inverse geography of high and low dividend payments revealed in section IV, it is notable that five of the twelve societies which allocated the recommended 2.5 per cent of profits to education were located in the Glasgow 
area. This suggests that there might be an association between relatively low dividends and relatively high levels of spending on education. To test this hypothesis, Pearson's correlation coefficient (r) was used to compare levels of dividend (Figure 3) and educational spending (Figure 4) in Midlothian (including Edinburgh) and Lanarkshire (including Glasgow) ${ }^{161}$. The results were: $1881, \mathrm{r}=.289, \mathrm{p}<.1 ; 1901, \mathrm{r}=.378, \mathrm{p}<.001 ; 1931, \mathrm{r}=.239, \mathrm{p}<.1$; and 1961, $\mathrm{r}=.517, \mathrm{p}<.001$. Though not large, the values of $\mathrm{r}$ suggest a correlation between levels of dividend and educational spending; which the p values show to be significant at the 99.9 per cent level in 1901 and 1961, and at the ninety per cent level in 1881 and 1931. These figures support the argument that, where levels of dividend were significantly higher or lower than the national average, as they were in the Edinburgh and Glasgow areas respectively, they were related to lower and higher levels of spending on education.

\section{VI}

Through the payment of a dividend on purchases, and by allocating funds for members' education, it seems reasonable to conclude that Scottish cooperatives were a large-scale alternative to joint-stock liberal capitalism. They demonstrated a significant, long-term commitment to generate and redistribute economic value to the less well-off, and provided opportunities for members to educate themselves both generally and in cooperative values.

However, it also emerged that there are likely to have been distinct cooperative cultures within Scotland. Clackmannanshire, Stirlingshire and Selkirkshire contained high concentrations of cooperative membership over several generations; and, while their origins are probably associated with high levels of 
employment in the textile industries, such traditions cannot be explained solely by economic factors. The same can be said of the distinct cultures of cooperation in the Glasgow and Edinburgh areas. Their economic structures differed (as noted above), and although the economic impacts of these differences remain uncertain ${ }^{162}$, Lee argued that the extent of service-sector employment provides a reasonable proxy measure of affluence and, on this basis, that Edinburgh was much wealthier than Glasgow ${ }^{163}$. This suggests that the tendency for cooperative societies located in the Glasgow area to pay lower dividends on purchases and to devote more funds per member to education, along with their efforts to extend the economic benefits of cooperation by paying a 'bonus on wages', are likely to be related to higher levels of solidarity among the area's working classes. Likewise, the propensity of societies in the Edinburgh area to pay higher dividends may reflect the wealth and embourgeoisement of the city.

\author{
Although further work is needed to test the extent to which cultures of \\ cooperation within Scotland were distinct and why, their likely existence \\ highlights the difficulty that alternative economic networks face in trying to \\ maintain their distinctive values and practices when they grow in scale. This is \\ because they tend to emphasise voluntary participation and local \\ organisation, which provide considerable latitude for local groups to engage in \\ 'alternative' economic activity according to their own values. In the case of \\ cooperation, the principle of voluntarism (enshrined in the Rochdale \\ principles) was dominant in Scottish societies by the 1870s. Membership was, \\ officially, open to anyone. Societies were independent, with considerable \\ freedom to think and act as they saw fit, provided they fulfilled their legal
}


obligations. While national bodies, such as the SCWS and the CU, could cajole and advise, they could not impose a unified way of operating, let alone unified cooperative values. This meant that the cooperative commonwealth could only come about when enough people joined cooperative societies, and when those societies operated in sufficient unison, to create the 'critical mass' that would somehow precipitate the transition from a capitalist to a cooperative economy ${ }^{164}$.

That critical mass did not materialise. Scottish membership peaked in the 1960s, and Pollard estimated in 1965 that about sixty-two per cent of all British households contained at least one society member ${ }^{165}$. However, these were the early years of the 'consumer society', and many people chose to be seduced into ever-increasing levels of consumption, thereby rejecting the sober, debt-free independence that thinkers like Holyoake saw as the foundation of the cooperative commonwealth ${ }^{166}$. This is unsurprising. Adopting and putting into practice alternative economic values requires considerable effort, combined with a belief that small-scale action can be effective at a distance and make a large-scale difference. Allowing oneself to be seduced into consumption, by contrast, leaves the difficult decisions and trade-offs inherent to economic activity to others and can provide a short-term emotional reward.

It is here that the parallels between historical Scottish consumer cooperation and current alternative economic networks are most apparent. For it seems that most consumers, given the choice, will choose to be seduced - by convenience, marketing and the perception of value for money - rather than 
reflect on the consequences of their consumption decisions as these ripple out in complex and often unpredictable ways across the economic networks that they help to sustain. Even among 'alternative hedonists', who are drawn from the ranks of the 'disillusioned seduced' and are considered to be in the vanguard of current attempts to think and act in ways that support alternative economic networks ${ }^{167}$, there is doubt about the extent to which small-scale actions can have large-scale impacts. As Barnett et al. found, considering the values instantiated by consumption behaviour can seem like going to too much trouble for an uncertain and often ambiguous outcome, especially when so much demands attention in the here-and-now ${ }^{168}$.

These parallels prompt two observations that might be useful to those currently engaged in efforts to conceptualise and support alternatives to neoliberal capitalism. The first is that cooperation provides a positive lesson from history'. Cooperative societies, most of which operate according to the Rochdale principles, have over 718 million owner-members worldwide ${ }^{169}$. This makes them arguably the most successful and enduring working-class influence on how to articulate and maintain alternatives to joint-stock (neo)liberal capitalism. However, this study suggests that alternative economic networks must operate and think in a different way if they are to redistribute economic value against the grain of (neo)liberal capitalism and convince and reassure members that their actions make a valuable contribution ${ }^{170}$.

The second observation is that such self-help-based economic activism has limited wider impact. Creating an alternative model that will, through voluntary means, displace the dominant political-economic paradigm is 
unlikely to succeed. Cooperation became a dominant force in Scottish food retailing, but this did not usher in a cooperative commonwealth. The history of Scottish cooperation in the nineteenth and twentieth centuries demonstrates that macro-scale political-economic change cannot be achieved solely through the till. To believe otherwise is to be seduced by one of the most potent myths of neoliberal capitalism: the myth of consumer sovereignty.

\footnotetext{
${ }^{1}$ Longley, Just Money, pp.8-10.

2 Longley, Just Money, p.14; Peck, 'Zombie neoliberalism', p.109; Smith, 'Neoliberalism'.

${ }^{3}$ Longley, Just Money, p.8.

${ }^{4}$ Krippner, 'The elusive market'; Lee, 'The ordinary economy'; Polanyi, The great transformation.

${ }^{5}$ Examples include: Barnett et al. Globalizing responsibility; Hinrichs, 'Food system localization'; Holloway and Kneafsey, 'Reading the space of the farmers market'; Ilbery and Kneafsey, 'Registering regional speciality food and drink products'; Ilbery and Kneafsey, 'Producer constructions of quality'; Ilbery and Maye, 'Alternative (shorter) food supply chains'; Ilbery and Maye, 'Food supply chains and sustainability'; Ilbery and Maye, 'Retailing local food'; Kirwan, 'Alternative strategies'; Lee, 'Shelter from the storm?'; Lee, 'The ordinary economy'; Leyshon et al. Alternative economic spaces; Morris and Buller, 'The local food sector'; Sage, 'Social embeddedness and relations of regard'; Tregear et al. 'Regional foods and rural development'; Watts et al. 'Networking practices among "alternative" food producers'.

${ }^{6}$ Leyshon and Lee, 'Introduction'.

${ }^{7}$ Coombes and Campbell, 'Dependent reproduction of alternative modes of agriculture'; Guthman, 'Commodified meanings and meaningful commodities'; Guthman, 'The trouble with "organic lite"; Hall and Mogyorody, 'Organic farmers in Ontario'; Smith and Marsden, 'Exploring the "limits to growth" in UK organics'; Tomlinson, 'Re-thinking the transformation of organics'.

8 Anderson, 'NGOs and Fair Trade'; Dolan, 'Virtual moralities'; Freidberg, 'Perspective and power in the ethical foodscape'; Goodman, 'Reading Fair Trade'; Goodman, 'The Mirror of Consumption'; Low and Davenport, 'Mainstreaming Fair Trade'; Mutersbaugh and Lyon, 'Transparency and Democracy in certified ethical commodity networks'; Raynolds, 'Mainstreaming Fair Trade coffee'; Smith, 'The search for sustainable markets'; Wilson, 'Indebted to Fair Trade?'; Wright, 'Consuming lives, consuming landscapes'.

9 Webster et al. The hidden alternative.

10 The Co-operative Group, the UK's largest mutually-owned business, declared a $£ 2.5$ bn loss in 2013 (as reported by the BBC - http://www.bbc.co.uk/news/business27049101; last accessed 16 October 2014), due primarily to financial misconduct and poor management in its now-demutualised banking operation (see Kelly, Failings in management and governance; and Goff, S., 'Cloggers to hedge funds - Co-op Bank's fall from grace', Financial Times, 8 November 2013 http://www.ft.com/cms/s/0/f6d1fdb0-460d-11e3-b49500144feabdc0.html\#axzz3GJnKXn31 - last accessed 16 October 2014 - respectively). ${ }_{11}$ A notable exception is Robertson, The cooperative movement.

12 For example: Battilani and Schröter, Co-operative business movement; Webster et al. The hidden alternative; Wilson et al. Building cooperation; and a special issue of Business History in 2012.
} 
13 Q.v. Kalmi, 'The disappearance of cooperatives'; Wilson et al. Building cooperation, p.3.

14 From 1 August 2014, Co-operative Society replaced Industrial and Provident Society as the legal term for a registered cooperative in the UK (http://www.fca.org.uk/firms/being-regulated/meeting-your-obligations / firmguides/cooperative-and-community-benefit--societies - last accessed 9 November 2014). For clarity, cooperative society is used throughout this paper.

15 Purvis, 'Societies of consumers'; Robertson, The cooperative movement.

16 Kinloch and Butt, History of the Scottish Co-operative Wholesale Society; Campbell, Co-operation in the Glasgow area.

17 Ware, Between profit and state, p.46.

18 Q.v. Cole, Century of co-operation, p.74; Wilson et al. Building Co-operation, pp.3742.

${ }^{19}$ See, e.g., Campbell, Co-operation in the Glasgow area, p.501; Donnelly, Goal Displacement.

20 Pollard, 'Nineteenth-century cooperation'.

${ }^{21}$ Webster et al. 'The hidden alternative?', p.9.

22 Wilson et al. Building cooperation, p.14.

23 Campbell, Co-operation in the Glasgow area, p.501.

${ }^{24}$ Ware, Between Profit and State, pp.48-9.

25 This distinction is developed in Lee, 'The ordinary economy'.

${ }^{26}$ Membership is open; each member has one vote regardless of their share holding; profits are disbursed on the basis of active participation in the business; and investors must not be the primary beneficiaries of cooperative economic activity on the basis of their investment (http://www.legislation.gov.uk/ukpga/2010/7/section/1 - last assessed 16 October 2014).

${ }^{27}$ Des Forges, 'We make millions of pairs of boots, but not one pair of millionaires', p.48.

28 Lancaster and Maguire, 'Co-operative movement', p.8.

29 Jones, Co-operative production; Holyoake, The cooperative movement today.

30 Gurney, 'Heads, hands and the co-operative utopia'.

31 Bonner, British co-operation, p.477.

32 See, e.g. The Scottish Co-operator, 13 March 1903, p.213; 28 July 1911, pp.682-3; 13 December 1912, pp.1189-90; 9 January 1914, p.33; 15 October 1915, p.989; 12 August 1921, p.698; 6 January 1923, p.13; 17 January 1925, p.57; 17 September 1927, p.1014. See also Gurney, Cooperative culture, pp.153-5; Hardie, The cooperative ideal'; Holyoake, The cooperative movement today, p.150.

${ }^{33}$ Gray, 'True aims and ideals of cooperation', p.575.

${ }^{34}$ Ibid.

35 Gurney, Cooperative culture, p.45. For a fuller account of the anticipated evolution of the cooperative commonwealth, see Bonner, British co-operation, chapter 18.

${ }^{36}$ Hilson, 'Consumers and politics', p.9.

37 Tanner, Political change and the Labour Party; Lawrence, Speaking for the people; cited by Hilson, 'Consumers and politics', p.9.

${ }^{38}$ Hilson, 'Consumers and politics', p.9.

39 Carr-Saunders et al. Consumers' Co-operation, p.517.

40 Barou, 'Whither co-operation?', p.13. See also Gurney, 'Heads, hands and the cooperative utopia', p.4; and Lancaster and Maguire, 'Co-operative movement', p.4.

${ }^{41}$ Gurney, 'Heads, hands and the co-operative utopia', p.14.

${ }^{42}$ Bonner, British co-operation, pp.478-9.

${ }^{43}$ Q.v. Campbell, Co-operation in the Glasgow area, p.351; Des Forges, 'We make millions of pairs of boots, but not one pair of millionaires'; Gurney, 'Heads, hands and the co-operative utopia'; Hilson, 'Consumers and politics'; Lancaster and Maguire, 'Cooperative movement'.

${ }_{44}$ Wilson et al. Building cooperation, p. 152.

45 Campbell, Co-operation in the Glasgow area; Kinloch and Butt, History of the SCWS. 
46 E.g. Des Forges, 'We make millions of pairs of boots, but not one pair of millionaires'; Hilson, 'Consumers and politics'; Robertson, 'We try to serve you in every possible way'.

47 Robertson, 'We try to serve you in every possible way', p.173.

48 Carr-Saunders et al. Consumers' Co-operation, p.523.

49 Burge, 'The co-operative movement in South Wales'; Campbell, Co-operation in the Glasgow area.

${ }^{50}$ Region is defined flexibly in this paper, as the scale between those of the nation and the individual local society.

${ }^{51}$ Carr-Saunders et al. Consumers' Co-operation, p.114.

52 Ibid.

53 For example: Des Forges, 'We make millions of pairs of boots, but not one pair of millionaires'; Hilson, 'Consumers and politics'; Robertson, 'We try to serve you in every possible way'.

${ }_{54}$ Purvis, 'Societies of consumers'; Robertson, The cooperative movement.

55 The National Archives provides a concise account of these developments: http:/ / discovery.nationalarchives.gov.uk/details/redirect/?CATLN=18CATID = 133\&C ATREF $=F S \& C A T L N=1 \&$ CATID $=1338_{2}$ SearchInit $=4 \&$ SearchType $=6 \& C A T R E F=F S ~-~ l a s t$ accessed 21 October 2014.

56 Compare Kinloch and Butt, History of the SCWS; and Wilson et al. Building cooperation.

57 Kinloch and Butt, History of the SCWS, pp.156-60.

58 Ibid. p.401, states that the first SCWS retail branch was opened in 1914. However, The Scottish Co-operator (25 June 1909, p.571) reports the opening of an SCWS retail branch in Elgin in October 1908, after the dissolution of the town's ailing cooperative society. This shop closed after 1918. The SCWS opened a more successful Elgin branch in 1933.

59 The Scottish Co-operator, 1 May 1893, p.1.

60 Maxwell, History of cooperation in Scotland, pp.24 \& 26 respectively.

61 Ibid. p. 47.

62 See the Remarks by the Registrar (A. Anderson) on p. 1 of one of the Reports of the Registrar of Friendly Societies in Scotland, for the Year 1873.

63 Abstract of returns furnished to the registrar of friendly societies in England by industrial and provident (cooperative) societies for the year ending 31 Dec. 1871. ${ }^{64}$ Abstract of returns furnished to the Registrar of Friendly Societies in England by industrial and provident (cooperative) societies for the year ending 31 Dec. 1872.

65 These were consulted at the National Co-operative Archive in Manchester. Neither they, nor the CU directories of cooperative societies, appear to have reference numbers; they were requested by title and date.

66 The actual figure is probably higher, as CU directories only contain information on cooperative societies that were thought to be trading at date of publication. Given the precarious finances of most early cooperative societies, many were short-lived.

67 Pollard 'Nineteenth-century cooperation', pp.106-7; Donnelly, Goal Displacement, p.58.

68 Mackintosh, 'Introduction', p.vi; Campbell, Co-operation in the Glasgow area, p.13.

69 Holyoake, The cooperative movement today, p.95.

70 Discussing Neale's role in drawing up this Act, Backstrom (Christian Socialism and co-operation in England, p.68) notes that 'seldom had an Act of Parliament owed so much to the efforts of a single individual'.

${ }^{71}$ Cole, A century of cooperation, pp.120-1.

72 Cole, A century of cooperation, p. 124.

${ }^{73}$ Figures derived from CU Congress reports for the years stated.

${ }^{74}$ For ease of comparison, county names have been modernised but boundaries have not. Thus, cooperative society membership in Scotland's four main cities is incorporated into the figures for the counties to which they originally belonged: Angus (Dundee), Lanarkshire (Glasgow), and Midlothian (Edinburgh); Aberdeen has been 
included in Aberdeenshire, although a small part of it was originally in Kincardineshire.

75 The LQ compares the number of instances of a given phenomenon (in this case members of cooperative societies) at two different spatial scales (in this case between Scotland and its historic counties). The formula is: Number of cooperative society members in county ' $y$ ' Number of cooperative society members in Scotland

$\mathrm{LQ}=$

\section{Population of county ' $y$ '}

Population of Scotland.

${ }^{76}$ Crawley et al., 'Making location quotients more relevant'.

77 Devine, 'Industrialisation', p.65; Devine, The Scottish nation, pp.261-3; Rodger, 'The labour force'.

78 Campbell, Co-operation in the Glasgow area, pp.23-4.

79 Gurney, 'Labour's Great Arch', p.155.

80 For example, Des Forges ('We make millions of pairs of boots, but not one pair of millionaires') study of Liverpool and the Rhondda valley.

81 Campbell, Co-operation in the Glasgow area, pp.279-80. Hilson ('Consumers and politics') encountered a similar difficulty in Plymouth.

82 Campbell, Co-operation in the Glasgow area, p.286.

83 The Scottish Co-operator, 20 March 1903, pp.223-4; 27 March 1903, p.253; 10 April 1903, p.296.

${ }^{84}$ Fraser, 'The working class', p.342; Maver, Glasgow, p.135.

85 Williams, Marxism and literature, p. 115.

86 Holyoake, The cooperative movement today.

87 Ibid., p.59.

88 Ibid., p.31.

89 Ibid., p.99.

90 Ibid., pp.103-4.

${ }^{91}$ Ibid., p.71.

92 Ibid., p.86.

93 Gurney, 'Heads, hands and the co-operative utopia', p.15; Robertson, 'We try to serve you in every possible way', p.185.

94 Whatmore et al. 'What's alternative about alternative food networks?'.

95 The 1872 Registrar's return to Parliament does not consistently list dividend payments in a format that enables such a comparison, so was excluded.

96 Robertson, 'We try to serve you in every possible way', p.178.

97 Gurney, 'Battle of the consumer in postwar Britain'.

98 The variables correlated are: net profit (as a percentage of sales) at decennial intervals 1881-1961; and member dividends per pound spent at the same intervals. 99 The mean of the differences between profit and dividend between 1911 and 1941 being more than one standard deviation larger than the overall mean.

100 Wilson et al. Building cooperation, p.157.

101 Ibid. p. 158.

102 Holyoake, The cooperative movement today, p.172.

103 Maxwell, History of cooperation in Scotland, p.371.

104 For instance, 4 March 1904, pp.201-2; 20 May 1904, p.455; 6 January 1905, p.20; 24 August 1917, p.582; 25 April 1925, p.401; 20 June 1928, p.707; 24 November 1928, p. 1287.

105 The Scottish Co-operator, 25 April 1925, p.401.

106 Carr-Saunders et al. (Consumers' co-operation, p.116) suggested that dividend exceeding two shillings and six pence in the pound was 'high', but their basis for doing so is unclear.

107 Observed in Scottish cooperative society returns to the CU. Carr-Saunders et al. (Consumers' co-operation, p.114) observed a similar effect at the British scale. 108 Carr-Saunders et al. Consumers' co-operation, p.115. 
109 Carr-Saunders et al. Consumers' co-operation, p.114.

110 The data sets are: dividend paid per pound spent (expressed as a percentage) for each society in Midlothian and in Lanarkshire.

${ }^{111}$ Kinloch and Butt, History of the SCWS, pp.156-60.

${ }^{112}$ Fraser, 'The working class', p.333.

113 Breitenbach and Wright, 'Women as active citizens', p.407.

114 Maver, Glasgow, p.159.

115 Smyth, Labour in Glasgow, p.47.

116 Campbell, Co-operation in the Glasgow area.

117 Campbell, Co-operation in the Glasgow area, p.354.

118 Campbell, Co-operation in the Glasgow area, p.364.

119 Smyth, Labour in Glasgow, p.47.

120 The Scottish Co-operator, 29 March 1930, p.301; 7 February 1931, p.133.

${ }^{121}$ See minutes of: special Board meetings of 18 January 1926 (11835/68, p.1375A), 5 May 1926 (p.1486), 9 May 1926 (p.1486A) and 20 May 1930 (11835/72); meetings of the Special Committee on Prices of 16 June 1931 (11835/73, p.3510), and of 1,15 and 29 September 1931 (11835/13); Board meetings of 19 December 1935 and 25 November 1937 (11835/140); and the Finance Committee meeting of 3 June 1938 (11835/109, p.227).

122 Minutes of the meeting of the Special Committee on Prices of 29 September 1931 $(11835 / 13)$.

123 Minutes of the meeting of the Drapery, Boots, Drugs, Coal \& Laundry Committee of 17 March 1930 (11835/72, p.3046).

${ }^{124}$ Lee, 'Establishment of the financial network', p.125.

125 Devine, 'Industrialisation', p.40.

126 Maver, Glasgow, p.135.

127 Holford, Reshaping labour, p.16; cited by Breitenbach and Wright, 'Women as active citizens', p.404.

128 Breitenbach and Wright, 'Women as active citizens', p.404.

129 Ibid.

130 Donnelly, Goal Displacement, p.292.

131 Gurney, Cooperative culture, p.29.

132 Pollard 'Nineteenth-century cooperation', p.111.

133 Cole, A century of cooperation, p. 227.

134 Cole, A century of cooperation, p.231.

135 Central Co-operative Board, Administration of educational grants.

136 Carr-Saunders et al. Consumers' co-operation, p.221; Donnelly, Goal Displacement, chapter 8; Gurney, Cooperative culture, p.35.

137 Gurney, Cooperative culture, p.48.

138 Ibid., pp.36-7.

139 Donnelly, Goal Displacement, p.294 et seq.

140 Central Co-operative Board, Administration of educational grants.

${ }^{141}$ Cole, A century of cooperation, p.234.

142 Letter from 'Lucifer' in The Scottish Co-operator, 21 October 1898, pp.356-7.

143 Gurney, Cooperative culture, p.32.

144 Holyoake, The cooperative movement today, p.79.

145 Ibid. p.86.

146 See, e.g. The Scottish Co-operator, 15 July 1898, p.223; 21 October 1898, p.356; 5 April 1901, p.126; 6 September 1901, p.329; 11 April 1902, p.219; 28 September 1925, p.942. See also Carr-Saunders et al. Consumers' co-operation, chapter 13; Gurney, Cooperative culture; Robertson, The cooperative movement, chapter 5.

147 Holyoake, The cooperative movement today, p.86.

148 Twigg, Cooperative education, Tables XIII \& XIV.

149 Ibid. Table XIV.

150 Ibid. Tables XIV \& XV.

151 Campbell, Co-operation in the Glasgow area, p.407. 
152 Gurney, Cooperative culture, p.49.

153 Editorial in The Scottish Co-operator, 16 June 1899, p. 207.

154 Maxwell, History of cooperation in Scotland, p.371.

155 Holyoake, The cooperative movement today, p.128.

156 The Royal Arsenal Society had the highest expenditure on education in England in the mid to late 1930s (Carr-Saunders et al. Consumers' co-operation, p.215).

157 Reeves, Education for social change, p.21.

158 The Scottish Co-operator, 15 July 1898, p.224; 11 April 1902, p.219.

159 Carr-Saunders et al. Consumers' co-operation, pp.217-19; Reeves, Education for Social Change, p.23.

160 Lucas, Cooperation in Scotland.

161 The variables correlated are: member dividend per pound spent, at decennial intervals 1881-1961; and educational spend (in pence) per member, at the same intervals.

162 Williams, 'Areas of high mortality: the case of Glasgow', pp.161-2.

163 Lee, 'Economic growth and structural change in Scotland'.

164 Q.v. Bonner, British co-operation, chapter 18.

165 Pollard, Cooperatives at the crossroads, p.3.

166 Gurney, 'Battle of the consumer in postwar Britain'.

167 Soper, 'Alternative hedonism', p.573.

168 Barnett et al. Globalizing responsibility.

$169 \mathrm{http}: / /$ ica.coop/en/whats-co-op/co-operative-facts-figures - last assessed 16 October 2014.

170 Anderson ('Cost of a cup of tea') provides an interesting parallel to this finding in his study of British cooperatives and Fair Trade. 


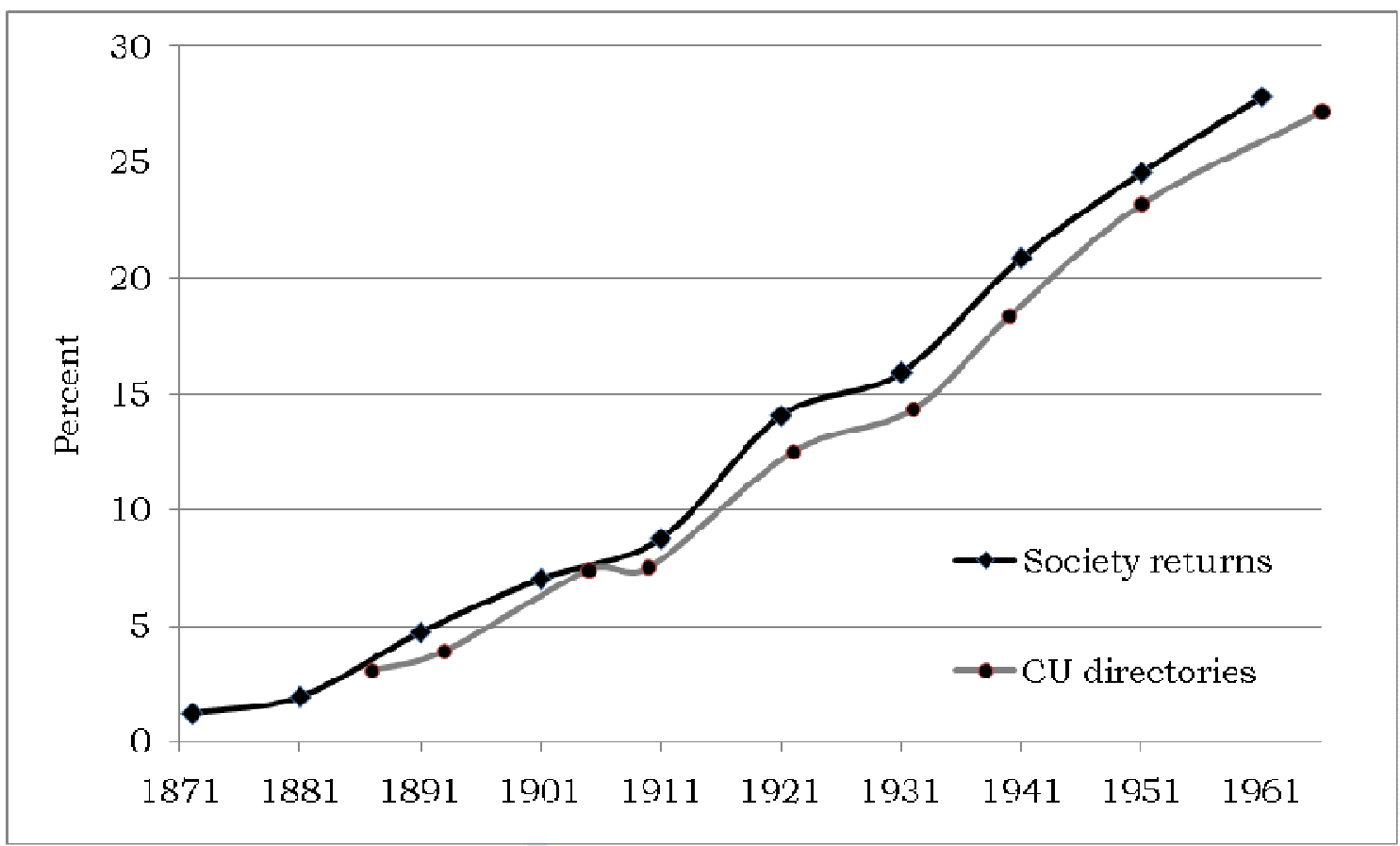

Figure 1. Consumer cooperative society membership as a percentage of the Scottish population, 1872-1966

Sources: Co-operative society returns to the Registrar (1872) and the CU (1881 on); CU directories of co-operative societies, 1887-1966;

General Register Office of Scotland, mid-year population estimates 18552013 (downloaded 14 July 2014 from http://www.groscotland.gov.uk/statistics/theme/population/estimates/mid-year/timeseries.html). 


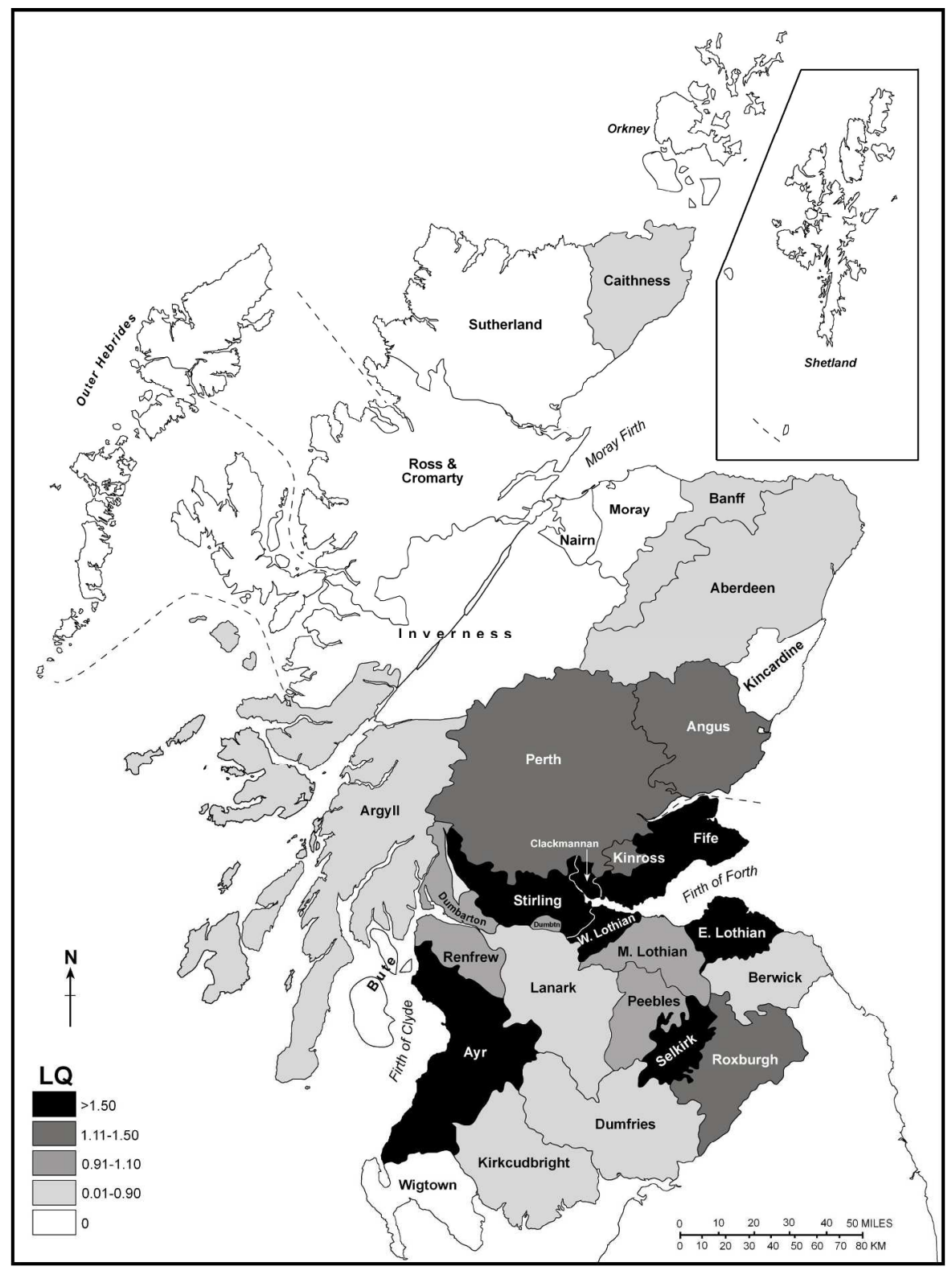

Figure 2a. Distribution of consumer cooperative society members in Scotland relative to population, by county, 1872 


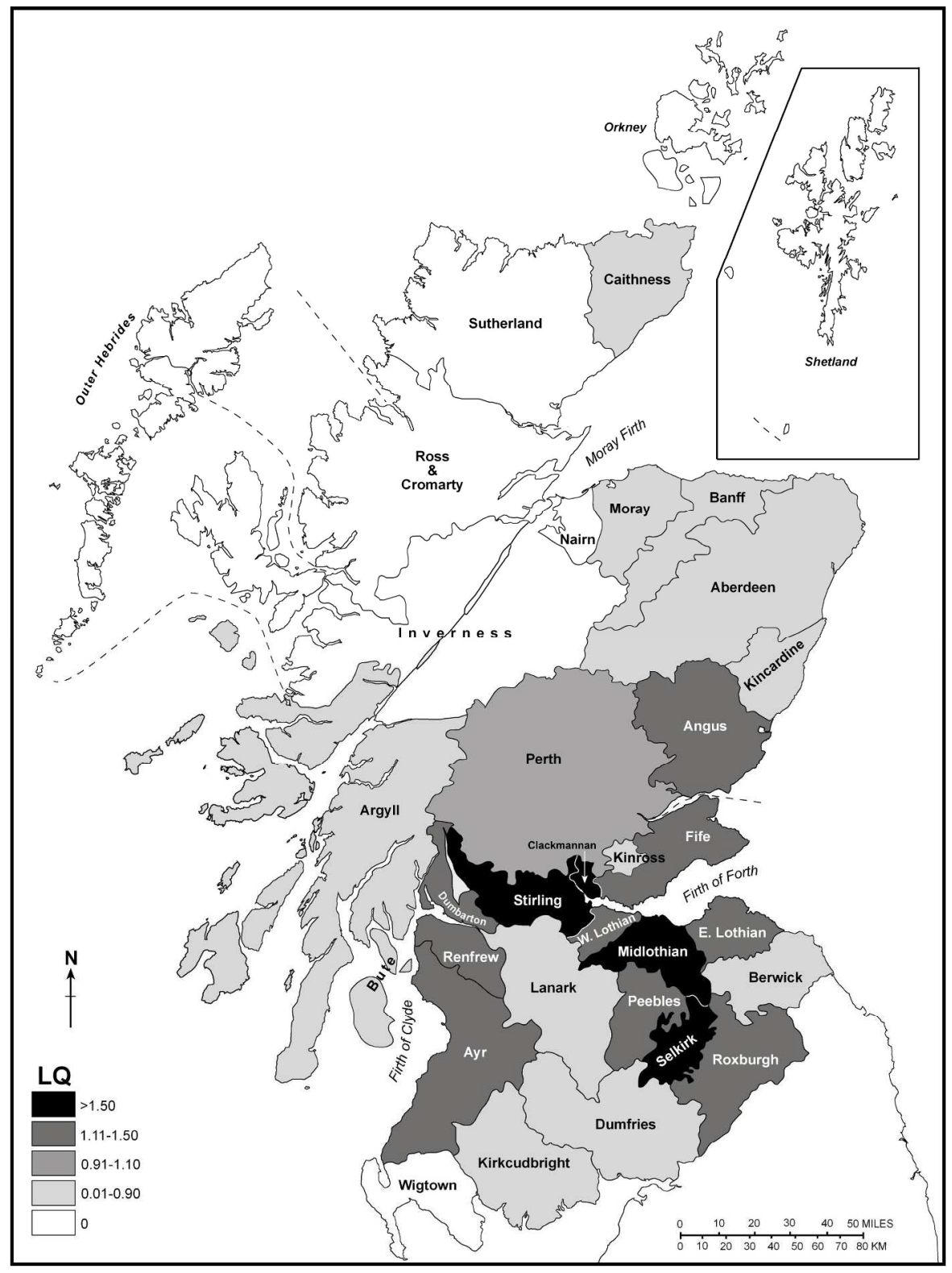

Figure 2b. Distribution of consumer cooperative society members in Scotland relative to population, by county, 1901 


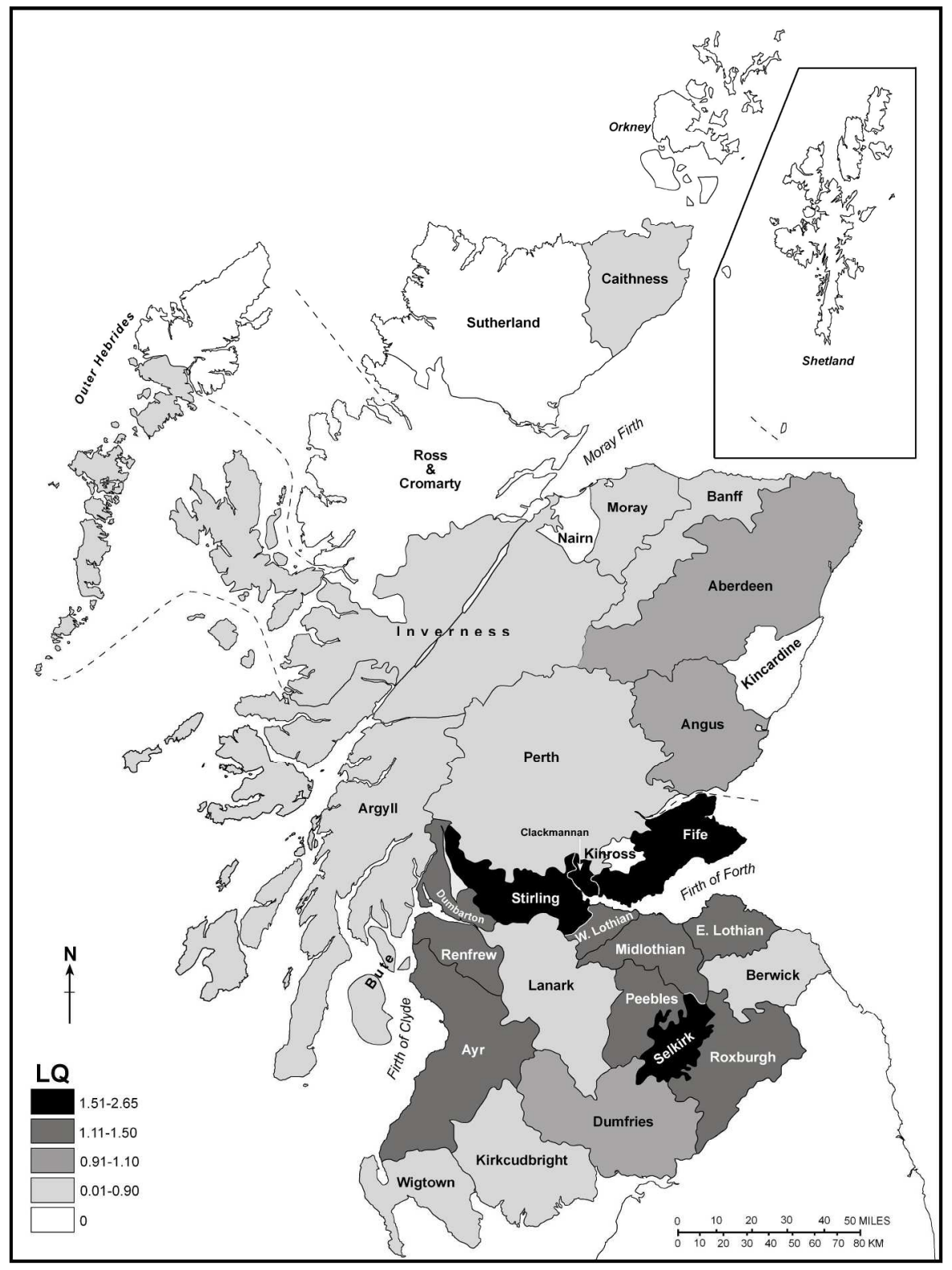

Figure 2c. Distribution of consumer cooperative society members in Scotland relative to population, by county, 1931 


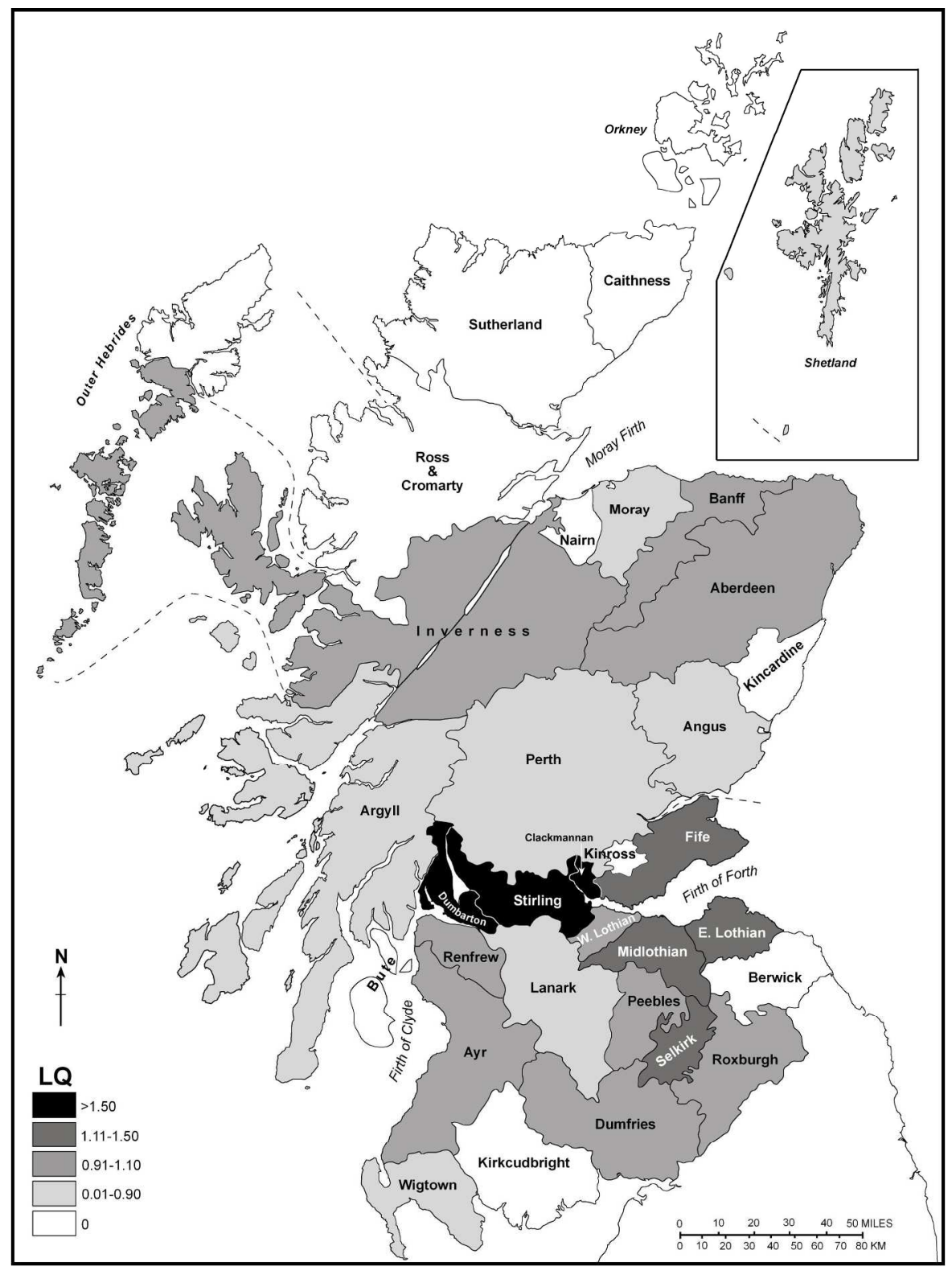

Figure 2d. Distribution of consumer cooperative society members in Scotland relative to population, by county, 1961 


\section{Sources for Figures 2a-2d}

Cooperative society membership figures are from cooperative society returns to the Registrar (1872) and the CU (1881 on);

County-level population figures are taken from the 1871, 1901, 1931 and 1961 censuses. The census figures for 1871,1901 and 1931 were downloaded from http://www.histpop.org/ on 30 July 2014.

13
14
15
16
17
18
19
20
21
22
23
24
25
26
27
28
29
30
31
32
33
34
35
36
37
38
39
40
41
42
43
44
45
46
47
48
49
50
51
52
53
54
55
56
57
58
59
60


Economic History Review

Page 42 of 53

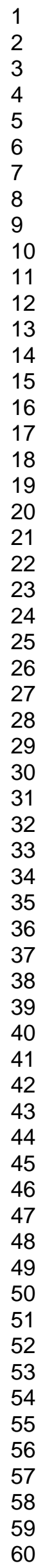

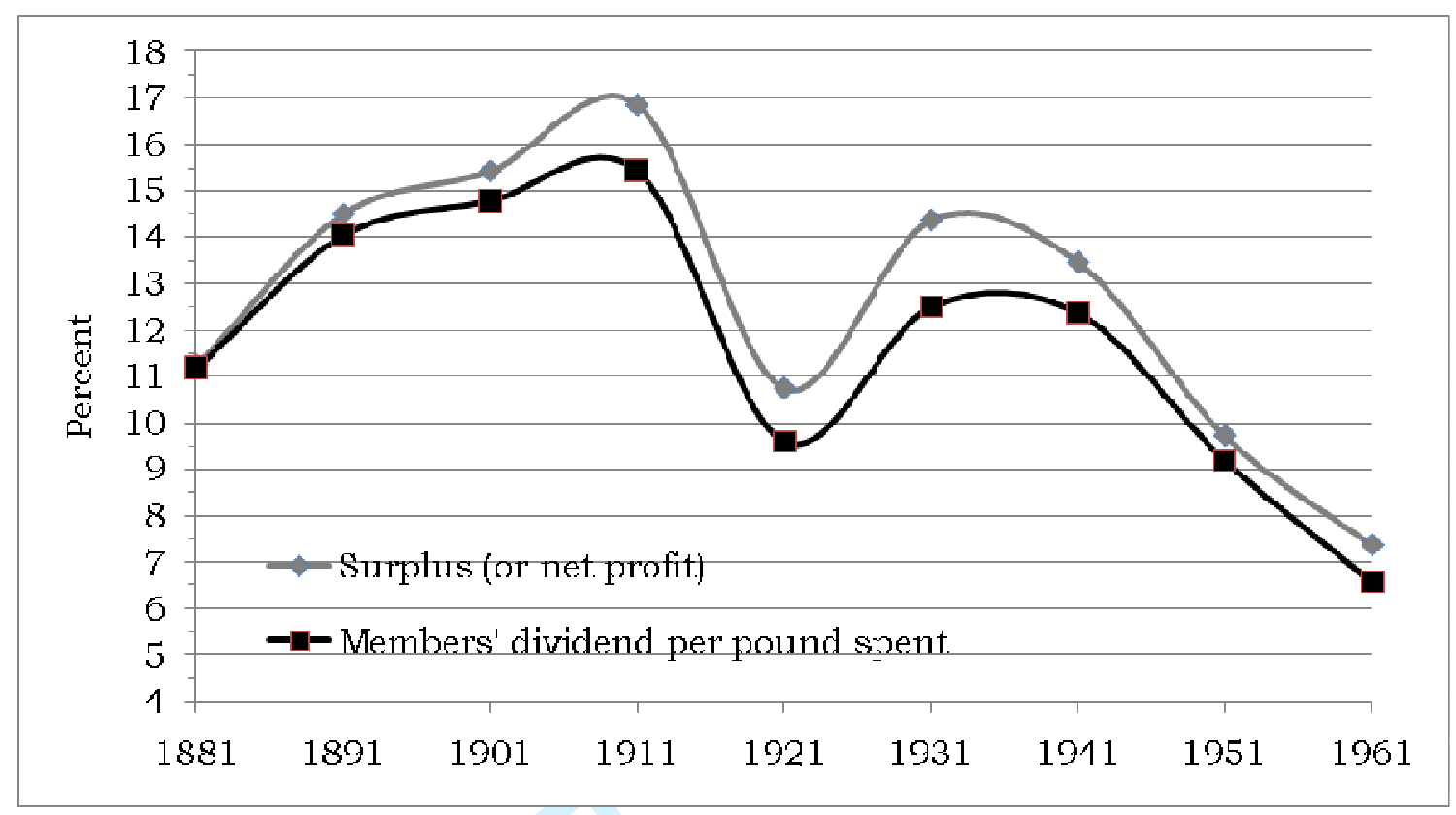

Figure 3. Net profit (as a percentage of sales) and average member dividends (per pound spent) for Scottish consumer cooperative societies, 1881-1961

Source: society returns to the CU. 


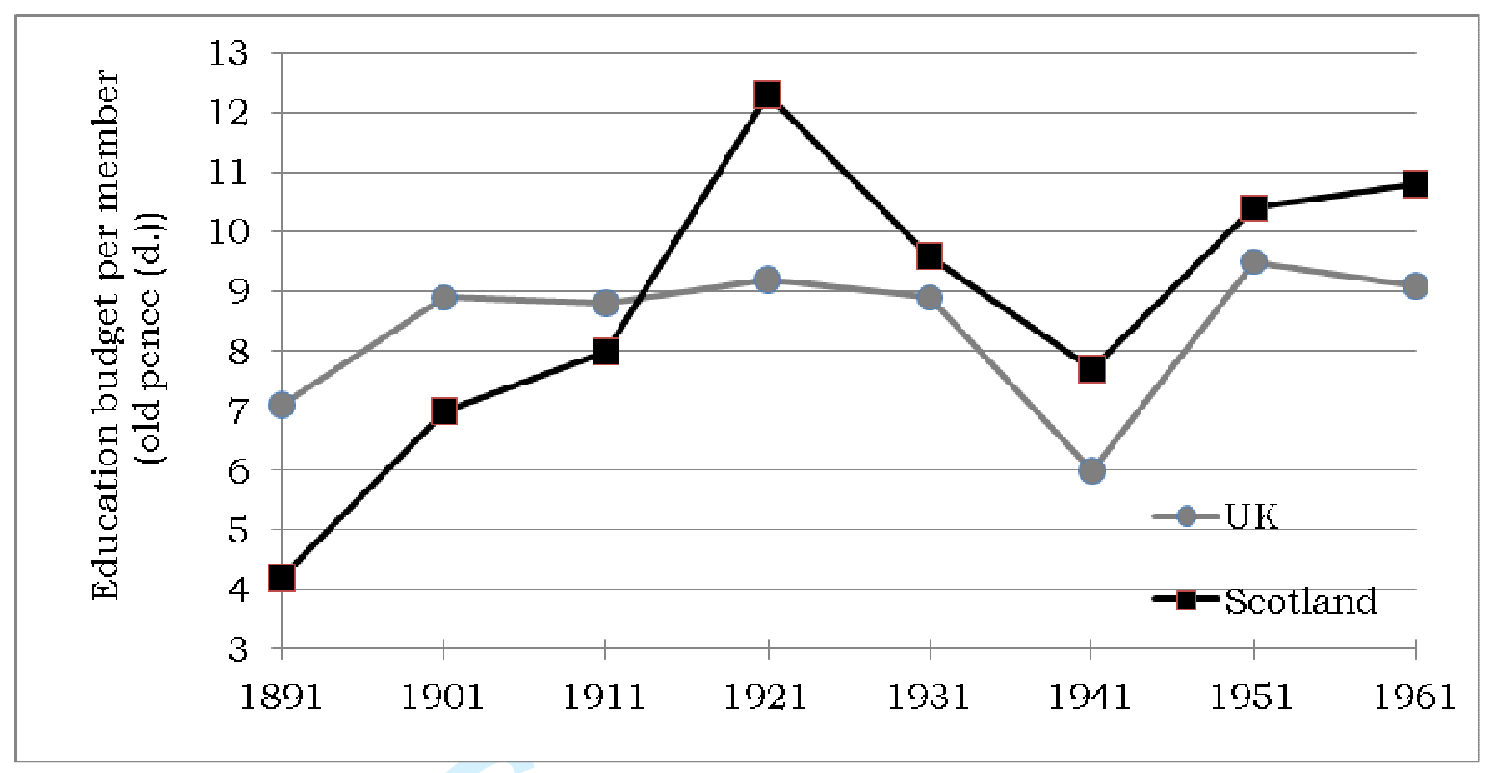

Figure 4. Educational budget per cooperative society member (in old pence) in the UK and Scotland, 1891-1961

Source: society returns to the CU. 
Table 1

Registrations and de-registrations of Scottish consumer co-operative societies, 1860-1913

\begin{tabular}{|c|c|c|}
\hline & \multicolumn{2}{|c|}{$\begin{array}{l}\text { Number of } \\
\text { societies }\end{array}$} \\
\hline Years & Added & Removed \\
\hline $1860-69$ & 203 & 5 \\
\hline 1870-79 & 146 & 101 \\
\hline 1880-89 & 102 & 45 \\
\hline 1890-99 & 49 & 41 \\
\hline 1900-09 & 20 & 41 \\
\hline 1910-13 & 6 & 17 \\
\hline Unknown & & 18 \\
\hline $\begin{array}{c}1860-1913 \\
\text { Net increase in societies, } \\
1860-1913\end{array}$ & $\begin{array}{l}526 \\
258\end{array}$ & 268 \\
\hline
\end{tabular}

Source: Register of Industrial and Provident Societies in Scotland, Volume 1 (National Archives of Scotland, FS8/16). 


\section{Footnote references}

\section{Bibliography}

Anderson, M., 'Cost of a cup of tea: Fair Trade and the British co-operative movement, c.1960-2000', in L. Black and N. Robertson, eds., Consumerism and the co-operative movement in modern British history (Manchester, 2009), pp. 24060.

Anderson, M., 'NGOs and Fair Trade: the social movement behind the label', in N. Crowson, M. Hilton and J. McKay, eds., NGOs in contemporary Britain (Basingstoke, 2009), pp. 222-41.

Backstrom, P. N., Christian Socialism and co-operation in England. Edward Vansittart Neale and the co-operative movement (1974).

Barnett, C., Cloke, P., Clarke, N. and Malpass, A., Globalizing responsibility. The political rationalities of ethical consumption (Chichester, 2011).

Barou, N., 'Whither co-operation?', in N. Barou, ed., The co-operative movement in a Labour Britain (1948), pp. 7-14.

Battilani, P. and Schröter, H. G., eds., The co-operative business movement, 1950 to the present (Cambridge, 2012).

Bonner, A., British co-operation. The history, principles, and organisation of the British co-operative movement (Manchester, 1970).

Breitenbach, E. and Wright, V., 'Women as active citizens: Glasgow and Edinburgh c.1918-1939', Women's History Review, 23(3) (2014), pp. 401-20.

Burge, A., The co-operative movement in South Wales and its history: "a task worthy of the most sincere devotion and application"', Welsh History Review, 23(4) (2007), pp. 59-71.

Campbell, A., Retail co-operation in the greater Glasgow area, ca. 1860-1914 (Ph.D. thesis, University of Strathclyde, 1983). 
Carr-Saunders, A. M., Florence, P. S. and Peers, R., Consumers' co-operation in Great Britain. An examination of the British co-operative movement (1938).

Cole, G. D. H., A century of cooperation (Manchester, 1944).

Central Co-operative Board, Return relating to the administration of educational grants in the various cooperative societies, together with the addresses of the secretaries of the educational departments so far as it has been possible to ascertain them (Manchester, 1889).

Coombes, B. and Campbell, H., 'Dependent reproduction of alternative modes of agriculture: organic farming in New Zealand', Sociologia Ruralis, 38 (1998), pp. $127-45$.

Crawley, A., Benyon, M., and Munday, M. 'Making location quotients more relevant as a policy aid in regional spatial analysis', Urban Studies, 50 (2013), pp. 185469.

Des Forges, J., "We make millions of pairs of boots, but not one pair of millionaires": co-operation and the working class in Liverpool and the Rhondda', North West Labour History, 19 (1994-5), pp. 48-64.

Devine, T. M., 'Industrialisation', in T. M. Devine, C. H. Lee and G. C. Peden, eds., The transformation of Scotland. The economy since 1700 (Edinburgh, 2005), pp. 34-70.

Devine, T. M., The Scottish nation, 1700-2007 (2006).

Dolan, C. S., 'Virtual moralities: the mainstreaming of fairtrade in Kenyan tea fields' Geoforum, 41 (2010), pp. 33-43.

Donnelly, R., Goal displacement and the British co-operative movement (Ph.D. thesis, Strathclyde University, 1980).

Fraser, W.H. 'The working class', in Fraser, W.H. and Maver, I. (eds) Glasgow. Volume II: 1830 to 1912 (Manchester, 1996), pp. 163-85. 
Freidberg, S., 'Perspective and power in the ethical foodscape' Environment and Planning A, 42 (2010), pp. 1868-74.

Goodman, M., 'Reading Fair Trade: political ecological imaginary and the moral economy of Fair Trade goods', Political Geography, 23 (2004), pp. 891-915.

Goodman, M. K., 'The mirror of consumption: celebretization, developmental consumption and the shifting cultural politics of Fair Trade', Geoforum, 41 (2010), pp. 104-16.

Gray, J. C. 'True aims and ideals of cooperation', inaugural address to the $38^{\text {th }}$ Annual Co-operative Congress, printed in The Scottish Co-operator, 15 June 1906, pp. 573-5.

Gurney, P., 'Heads, hands and the co-operative utopia', North West Labour History, 19 (1994-5), pp. 3-23.

Gurney, P., Cooperative culture and the politics of consumption in England, 18701930 (Manchester, 1996).

Gurney, P., 'Labour's Great Arch: cooperation and cultural revolution in Britain, 1795-1926', in E. Furlough and C. Strikwerda, eds., Consumers against capitalism? Consumer cooperation in Europe, North America, and Japan, 18401990 (Oxford, 1999), pp. 133-71.

Gurney, P., 'The battle of the consumer in postwar Britain', The Journal of Modern History, 77 (2005), pp. 956-87.

Guthman, J., 'Commodified meanings and meaningful commodities: re-thinking production-consumption links through the organic system of provision', Sociologia Ruralis, 42 (2002), pp. 295-311.

Guthman, J., "The trouble with "organic lite" in California: a rejoinder to the “conventionalisation” debate', Sociologia Ruralis, 44 (2004), pp. 301-16.

Hall, A. and Mogyorody, V., 'Organic farmers in Ontario: an examination of the conventionalisation argument', Sociologia Ruralis, 41 (2001), pp. 399-422. 
Hardie. J. K., 'The cooperative ideal', The Scottish Co-operator, 23 December 1904, p. 1211.

Hilson, M., 'Consumers and politics: the co-operative movement in Plymouth, 1890-1920', Labour History Review, 67 (2002), pp. 7-27.

Hinrichs, C., 'The practice and politics of food system localization', Journal of Rural Studies, 19 (2003), pp. 33-45.

Holford, J., Reshaping labour: organisation, work and politics - Edinburgh in the Great War and after (1988).

Holloway, L. and Kneafsey, M., 'Reading the space of the farmers market: a preliminary investigation from the UK', Sociologia Ruralis, 40 (2000), pp. 285-99.

Holyoake, G. J., The cooperative movement today (1903).

Ilbery, B. and Kneafsey, M., 'Registering regional speciality food and drink products in the United Kingdom: the case of PDOs and PGIs', Area, 32 (2000), pp. 317-25.

Ilbery, B. and Kneafsey, M., 'Producer constructions of quality in regional speciality food production: a case study from South West England', Journal of Rural Studies, 16 (2000), pp. 217-30.

Ilbery, B. and Maye. D., 'Alternative (shorter) food supply chains and specialist livestock products in the Scottish-English Borders', Environment and Planning A, 37 (2005), pp. 823-44.

Ilbery, B. and Maye. D., 'Food supply chains and sustainability: evidence from specialist food producers in the Scottish/English Borders', Land Use Policy, 22 (2005), pp. 331-44.

Ilbery, B. and Maye. D., 'Retailing local food in the Scottish-English Borders: a supply chain perspective', Geoforum, 37 (2006), pp. 352-67.

Jones, B., Co-operative production (2 volumes) (Oxford, 1894).

Kalmi, P., 'The disappearance of cooperatives from economics textbooks', Cambridge Journal of Economics, 31 (2007), pp. 625-47. 
Kelly, C., Failings in management and governance. Report of the independent review into the events leading to the Co-operative Bank's capital shortfall (Manchester, 2014).

Kinloch, J. and Butt, J., History of the Scottish Co-operative Wholesale Society Limited (Manchester, 1981).

Kirwan, J., 'Alternative strategies in the UK agro-food system: interrogating the alterity of farmers' markets', Sociologia Ruralis, 44 (2004), pp. 395-415.

Krippner, G. R., 'The elusive market: embeddedness and the paradigm of economic sociology', Theory and Society, 30 (1991), pp. 775-810.

Lancaster, B. and Maguire, P., 'The co-operative movement: a historical perspective', in B. Lancaster and P. Maguire, eds., Towards the cooperative commonwealth: 150 years of cooperation. Essays in the history of cooperation (Manchester, 1996), pp. 3-15.

Lawrence, J., Speaking for the people: party, language and popular politics in England, 1867-1914 (Cambridge, 2002).

Lee, C. H., 'Modern economic growth and structural change in Scotland: the service sector reconsidered', Scottish Economic and Social History, 3 (1983), pp. 5-35.

Lee, C. H., 'The establishment of the financial network', in T. M. Devine, C. H. Lee and G. C. Peden, eds., The transformation of Scotland. The economy since 1700 (Edinburgh, 2005), pp. 100-27.

Lee, R., 'Shelter from the storm? Geographies of regard in the worlds of horticultural production and consumption', Geoforum, 31 (2000), pp. 137-57.

Lee, R., 'The ordinary economy: tangled up in values and geography', Transactions of the Institute of British Geographers, NS 31 (2006), pp. 413-32.

Leyshon, A. and Lee, R., 'Introduction', in A. Leyshon, R. Lee, and C. C. Williams, eds., Alternative economic spaces (2003), pp. 1-26.

Leyshon, A., Lee, R., and Williams, C. C., eds., Alternative economic spaces (2003). 
Longley, C., Just money: how Catholic social teaching can redeem capitalism (2014).

Low, W. and Davenport, E., 'Mainstreaming Fair Trade: adoption, assimilation, appropriation', Journal of Strategic Marketing, 14 (2006), pp. 315-27.

Lucas, J., Cooperation in Scotland (Manchester, 1920).

Mackintosh, R., 'Introduction', in W. Maxwell, History of cooperation in Scotland. Its inception and its leaders (Glasgow, 1910), pp. vi-viii.

Maver, I., Glasgow (Edinburgh, 2000).

Maxwell, W., History of cooperation in Scotland. Its inception and its leaders (Glasgow, 1910).

Morris, C. and Buller, H., The local food sector. a preliminary assessment of its form and impact in Gloucestershire', British Food Journal, 105 (2003), pp. 55966.

Mutersbaugh, T. and Lyon, S., 'Transparency and democracy in certified ethical commodity networks', Geoforum, 41 (2010), pp. 27-32.

Peck, J., 'Zombie neoliberalism and the ambidextrous state', Theoretical Criminology, 14 (2010), pp. 104-10.

Polanyi, K., The great transformation: the political and economic origins of our time (Boston, Mass., 2001 [1944]).

Pollard, S., The cooperatives at the crossroads (1965).

Pollard, S., 'Nineteenth-century cooperation: from community building to shopkeeping', in A. Briggs and J. Saville, eds., Essays in labour history (1967), pp. 74-112.

Purvis, M., 'Societies of consumers and consumer societies: cooperation, consumption and politics in Britain and Continental Europe, c. 1850-1920', Journal of Historical Geography, 24 (1998), pp. 147-69.

Raynolds, L., 'Mainstreaming Fair Trade coffee: from partnership to traceability', World Development, 37 (2009), pp. 1083-93. 
Reeves, J., Education for social change. A demand that cooperative education should prepare men, women and children for the new world (Manchester, 1936).

Robertson, N., The cooperative movement and communities in Britain, 1914-60: minding their own business (Farnham, 2010).

Robertson, N., "We try to serve you in every possible way": the Ewloe Place Cooperative Society and the Ton Industrial Co-operative Society during the interwar years', Llafur, 11 (2012), pp. 170-88.

Rodger, R., 'The labour force', in W. H. Fraser and I. Maver, eds., Glasgow. Volume II: 1830 to 1912 (Manchester, 1996), pp. 163-85.

Sage, C., 'Social embeddedness and relations of regard: alternative "good food" networks in South-West Ireland', Journal of Rural Studies, 19 (2003), pp. 47-60.

Smith, E. and Marsden, T., 'Exploring the "limits to growth" in UK organics: beyond the statistical image', Journal of Rural Studies, 20 (2004), pp. 345-57.

Smith, J., The search for sustainable markets: the promise and failures of Fair Trade', Culture \& Agriculture, 29 (2007), pp. 89-99.

Smith, N., 'Neo-liberalism: dead but dominant', Focaal, 51 (Summer, 2008), pp. $155-7$.

Smyth, J.J., Labour in Glasgow 1896-1936: Socialism, suffrage, sectarianism (East Linton, 2000).

Soper, K., 'Alternative hedonism, cultural theory and the role of aesthetic revisioning', Cultural Studies, 22 (2008), pp. 567-87.

Tanner, D., Political change and the Labour Party, 1900-1918 (Cambridge, 1990). Tomlinson, I., 'Re-thinking the transformation of organics: the role of the UK Government in shaping British organic food and farming', Sociologia Ruralis, 48 (2008), pp. 133-51. 
Tregear, A., Arfini, F., Belletti, G. and Marescotti, A., 'Regional foods and rural development: the role of product qualification', Journal of Rural Studies, 23 (2007), pp. 12-22.

Twigg, H. J., An outline history of cooperative education (Manchester, 1924).

Ware, A., Between profit and state. Intermediate organizations in Britain and the United States (Cambridge, 1989).

Watts, D., Ilbery, B., and Jones, G., 'Networking practices among "alternative" food producers in England's West Midlands region', in D. Maye, L. Holloway and M. Kneafsey, eds., Constructing alternative food geographies: representation and practice (Amsterdam, 2007), pp. 289-307.

Webster, A., Shaw, L., Stewart, D., Walton, J. K., and Brown, A., 'The hidden alternative?', in A. Webster, L. Shaw, J. K. Walton, A. Brown, and D. Stewart, eds., The hidden alternative. Cooperative values, past, present and future (Manchester, 2011), pp. 1-15.

Webster, A., Shaw, L., Walton, J. K., Brown, A., and Stewart, D., eds., The hidden alternative. Cooperative values, past, present and future (Manchester, 2011).

Whatmore, S., Stassart, P., and Renting, H., 'What's alternative about alternative food networks?', Environment and Planning A, 35 (2003), pp. 389-91.

Williams, R., Marxism and literature (Oxford, 1977).

Williams, R., 'Medical, economic and population factors in areas of high mortality: the case of Glasgow', Sociology of Health \& Ilness, 16 (1994), pp. 143-81.

Wilson, B. R., 'Indebted to Fair Trade? Coffee and crisis in Nicaragua', Geoforum, 41 (2010), pp. 84-92.

Wilson. J. F., Webster, A. and Vorberg-Rugh, R., Building cooperation. A business history of the Co-operative Group, $1863-2013$ (Oxford, 2013). 
Wright, C., 'Consuming lives, consuming landscapes: interpreting advertisements for Cafédirect coffees', Journal of International Development, 16 (2004), pp. 66580.

\section{Official sources}

Industrial and provident (cooperative) societies. Abstract of returns furnished to the registrar of friendly societies in England by industrial and provident (co-operative) societies for the year ending 31 December 1871, with summary for each county in England and Wales; list of societies dissolved to 31 December 1871; list of societies which have neglected to make returns to the registrar for the year ending 31 December 1871; list of new societies registered during the year 1871; and, similar returns from the registrars of friendly societies in Scotland and Ireland (P.P. 1872, 418).

Industrial and provident (cooperative) societies. Abstract of returns furnished to the Registrar of Friendly Societies in England by industrial and provident (cooperative) societies for the year ending 31 December 1872, with summary for each county in England and Wales; list of societies dissolved to 31 December 1872; list of societies which have neglected to make returns to the registrar for the year ending 31 December 1872; list of new societies registered during the year 1872; and, similar returns from the registrars of friendly societies in Scotland and Ireland (P.P. 1873, 217).

National Library of Scotland, Records of the Scottish Midland Co-operative Society Ltd, Acc. 11835.

National Records of Scotland Register of Industrial and Provident Societies in Scotland, Volume 1, FS8/16.

National Records of Scotland Reports of the Registrar of Friendly Societies in Scotland, for the Year 1873, SRO15/63. 